\title{
A Shoreline Change Detection (2012-2021) and forecasting Using Digital Shoreline Analysis System (DSAS) Tool: A Case Study of Dahej Coast, Gulf of Khambhat, Gujarat, India.
}

\author{
Mousumi Dey ${ }^{1}$, Shanmuga Priyaa $\mathrm{S}^{2 \star}$ and B.K. Jena ${ }^{3}$ \\ ${ }^{1} \mathrm{M}$. Tech in Geoinformatics, Department of Geography, University of Madras, Chennai-600025, ${ }^{2}$ Project Scientist, Coastal \& \\ Environmental Engineering, National Institute of Ocean Technology, Chennai-600100, ${ }^{3}$ Scientist F, Coastal \& Environmental \\ Engineering, National Institution of Ocean Technology, Chennai-600100
}

Received: 2020-10-05

Accepted: 2021-04-26

Keywords:

DSAS; Uncertainty; Multi-date data;

Correspondent email:

sspriyaa@niot.res.in

\begin{abstract}
Shoreline is one of the coastal landforms which continuously changing in nature. Hence, monitoring of shoreline change is very obligate to understand and manage the coastal process. The objectives of the present study were i) to identify the shoreline change detection (2012 to 2021) based on various statistical methods along Dahej coast, Gujrat. ii) to forecast the shoreline position after 10 years. DSAS tool and Multi-dated satellite images (Sentinel-2 and LISS-IV) were used in present study. The result shows that, the pattern of rate of change was more or less similar with little variation in the values for the 3 different methods. Highest erosion rate was for End Point Rate, Linear Regression Rate and Weighted Linear Regression rate found $-33 \mathrm{~m},-31 \mathrm{~m},-31 \mathrm{~m}$ respectively at transect no 54 . Highest accretion rate was $38 \mathrm{~m}$ (EPR), 50m (LRR), 51m (WLR) along a particular transect. The forecast of shoreline position for the year 2032 observed through Kalman Filter Model. Seasonal analysis for 3 years $(2016,2017,2018)$ shows the region not having any seasonal pattern.
\end{abstract}

\section{Introduction}

Shoreline position changes have become, in recent years, one of the major environmental problems affecting the coastal zones worldwide. Indeed, nearly $80 \%$ of the world's coasts are eroding (Kermani et al., 2016). The shoreline is a geomorphological entity that refers the zone between high tidewater and low tide water which is consistent changes depending on natural as well as erosion and accretion due to manmade activities for coastal development (Shin and Kim, 2015). The shoreline change destroys the coastal environment and threatens the structures on the coast. Some factors which are very effecting to change of shoreline are Tide, Wave, Nearshore currents and manmade activities. Shoreline change is one of the most recurrent natural hazards in the world, which causes a serious menace to the coastal environment, human life and property (Mohan et al., 2005). It potentially generates a more severe impact on the environments and human life especially due to the complexity and dynamics of environmental and social processes in an area. Hence the analysis of shoreline change plays a crucial role in coastal risk management and planning (Mutaqin, 2017). In the prolonged history of human settlement inside or near the coastal zone, it is necessery to identify shoreline position and analyze its variation over time and space (Burninghan and Fernandez-Nunez, 2020). Through numerical method calibration and verification, sea-level rise assessment, and hazard zone development, as well as the policy-making process of coastal area development (Yadav et al, 2018). As we knew that Tidal range increases from south to north with the value ranging from $0.9-1.8 \mathrm{~m}$. in case of Gulf of Khambhat tidal range is the largest along the Indian coastline. Semi-diurnal tides of the
Gulf of Khambhat amplify about threefold from mouth to head. So, the tidal effect is the major cause of shoreline change of this study area. On account of the large tidal range, robust currents are found in the gulf. (Nayak and Shetye, 2003). 8-11m tidal range observed with strong tidal currents. Tidal currents are the horizontal water movements corresponding to the rise and fall of the tide.

Several studied has been carried out by the researchers for different study areas. Net rates changes of shoreline position in time were calculated from several statical methods End Point Rate (EPR), Linear Regression Rate (LRR), Weighted Linear Regression Rate (WLR) by using remotely sensed data. (Kermani et al., 2016; Appeaning Addo, 2015; Kankara et al., 2015). The shoreline evolution along Elamina, Cape Coast and Maree coast of Ghanawith the analysis net shoreline movement and EPR statistics were generated by Digital shoreline Analysis System (DSAS)tools (Jonah et al., 2016). The investigation of erosion and accretion rate by calculating EPR with the help of DSAS tools were done using Landsat data. (Vivek et al., 2019). A study has been carried out on Estuarine shoreline change analysis along with the Ennore river mouth, south-east coast of India, using digital shoreline analysis system (Nithu, et al., 2019). Multi-date shoreline maps were digitized and projected using polygonal using Arc -GIS and were overlaid using tic coordinates of the study area and an overlaid map was edited and labelled and finally, shoreline changed map was generated using intercept options of ArcView (Thangaraj, 2019). Long term shoreline changes along the southwest coast of India by using DSAS software to compute the rate of shoreline change (Nair et. al., 2018). Automatic shoreline change detection (Kuleli et al., 2011; 
Moussaid et al., 2015). In the coastal areas, shoreline is one of the instantaneously changing landforms and these are key components of coastal GIS (Sheik and Chandrasekar, 2011). The rate of shoreline changes is estimated by three statistical methods EPR, LRR and Least Median of Square (LMS) by using DSAS software (Sheik and Chandrasekar, 2011). Erosion of high tidal mudflats in the northern Gulf of Khambhat was studied by the Bhatti et al. (2018). Estimation of shoreline change analysis using digital shoreline analysis system, Kanyakumari and Tuticorin coast (Sheik and Chandrasekar, 2011). The multi-date IRS and Landsat satellite data are used to extract the shoreline. The rate of shoreline change is estimated by the three statistical method e. g. EPR, LRR, LMS by using DSAS. Estimation of shoreline change using high-resolution images along Gwanganri Beach using video monitoring system, ground control point, ortho Arial photos for extracting the shoreline. (Shin and Kim, 2015). The shoreline change threat to coastal zone: a case study of Karwar coast has been carried out by Yadav et al. (2018). A study was recently done on Spatio-temporal analysis of shoreline change along the coast of Sayung, Demak, Indonesia using the Digital Shoreline Analysis System (Muskananfola et al., 2020). A study was done in the region of Gulf of Khambhat for the year 2016 to 2018 using Landsat data with visual interpretation. They dose not calculate any rate of change(Bansal, 2020). Another study was carried out for the year 1990 -2014 using Landsat data in part of Gulf of Khambhat with two different method i.e., NSM and EPR for rate calculation (Misra and Balaji, 2015).

DSAS software provides a flexible environment for statistical analysis of shoreline change. This system follows a piece of particular information like shoreline, date, uncertainty, length of shoreline and transect. There are numbers of statistical methods used for calculating the rate of shoreline change, such as SCE (Shoreline Change Envelope), NSM (Net Shoreline Movement), LRR (Linear Regression Rate), EPR (End Point Rate), WLR (Weighted Linear Regression), LSM (Least Median of Square). In this study we have calculated SCE, NSM, EPR, LRR, WLR with their uncertainty and error calculation by measuring EPRunc (Uncertainty of End Point Rate), LR2 (R square of Linear Regression), and WR2 ( $\mathrm{R}$ square of Weighted linear Regression) methods. The specialty of this present study is, here we have tried to recognized the rate of shoreline change by the help of quite high-resolution images than the previous studies in this region. Also, we have tried to came out a comparative study on various methods of rate measurement and finally this study will give a visual identification of the future shoreline position (forecast of shoreline) for next 10and 20-years interval in this study area.

The present study area is Dahej coast located in Gujrat coast which is an inner part of the Gulf of Khambhat (Figure 1). Latitudinal extension $21^{\circ} 39^{\prime}$ to $21^{\circ} 45^{\prime} \mathrm{N}$ and Longitudinal extension $72^{\circ} 31^{\prime}$ to $72^{\circ} 37^{\prime} \mathrm{E}$. It's located between two estuaries, in south Narmada river estuaries and northern portion Dhadar river estuaries. The length of the shoreline of the study area is approximate $16 \mathrm{~km}$. Gulf of Khambhat is characterized by several large and small estuaries like Narmada, Tapti, Mahi, Sabarmati, Dadar, Kim. The erosional processes are predominant in Mahi estuary while depositional activities are dominating in the Narmada estuary (Shaikh et al., 1989). Currents are one of the most important factors for coastal morphology. In the case of the Gulf of Khambat, currents are mainly influenced by strong

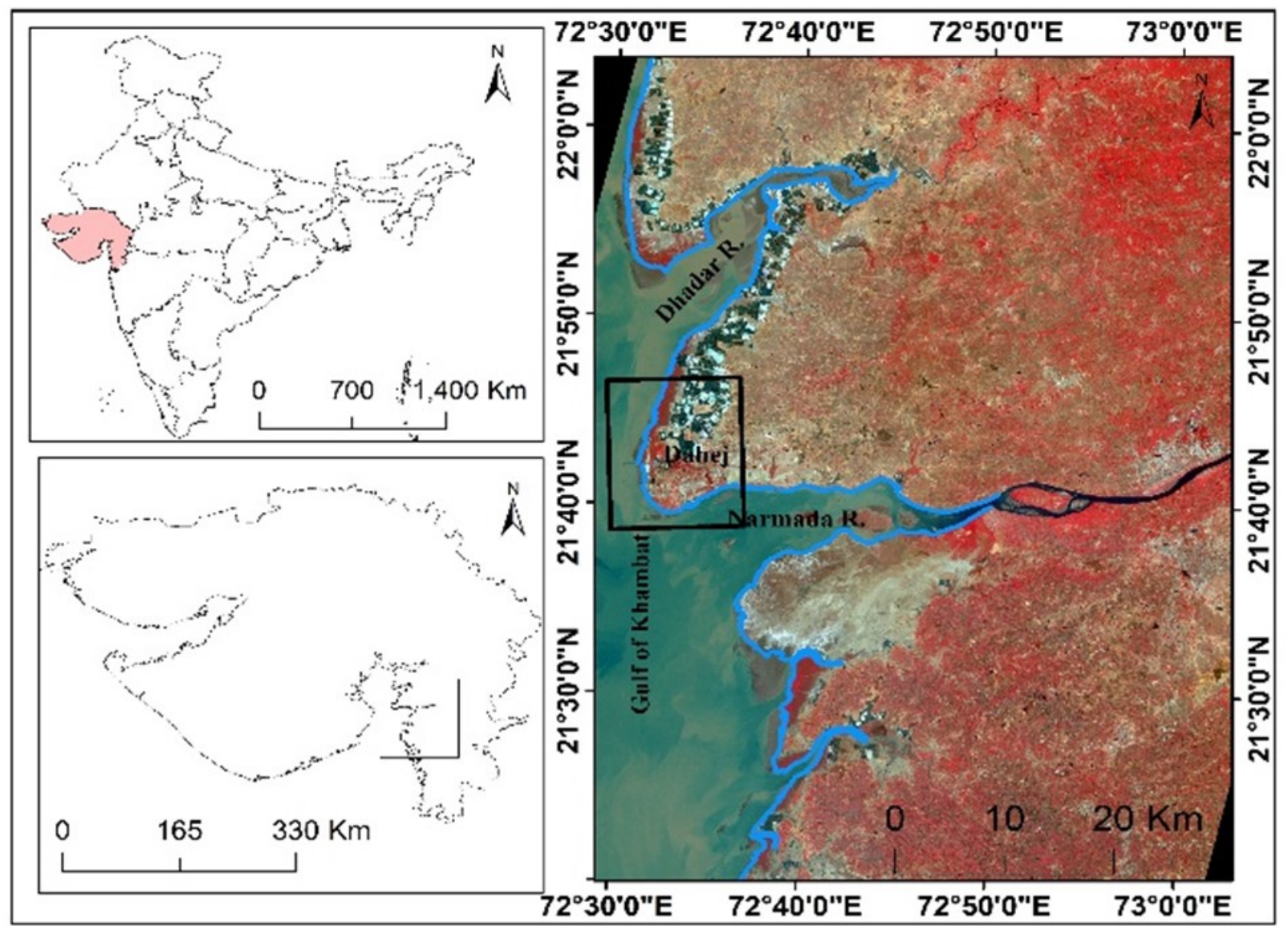

Figure 1. Study Area 
tides (Nayak and Sahai 1985). When the currents are strong, they will have a significant influence on wave propagation and it also effects on the shoreline. Dahej coast is located in the inner gulf, it facing strong currents during the flood tides. Nearshore current of the Dahej coast is 3.3 to $3.5 \mathrm{~m} / \mathrm{s}$. Strong tidal currents are dominating in the Gulf of Khambhat that causes most of the erosion and deposition in this region (Bansal, 2020). Due to its geographical location, the present study area facing large tidal range with the strongest semi-diurnal tide. Mudflats are observed in this study area through satellite images which indicate the large intertidal zone. The shoreline is highly fluctuating in mudflats region due to soft sedimentary deposit. The climate is tropical humid with the dry winter season. More than $80 \%$ of total annual rainfall experiences during the south-west monsoon period. As per multi-dates satellite imagery, mangroves were not present along Dahej coast in past. Recently mangroves are found in this region by observing satellite imagery. Mangroves also play a positive impact on the shoreline; it can protect the shoreline from high erosion.

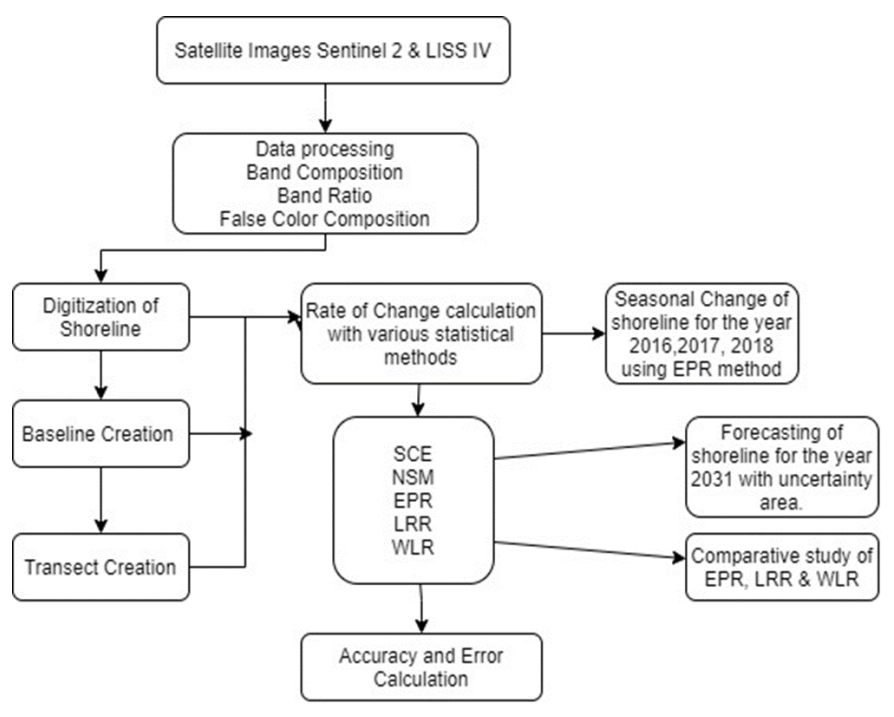

Figure 2. Flow chart for methodology

\section{Methods}

\section{Data Collection and Processing}

The LISS IV (Linear Imaging Self-Scanning Sensor) data was purchased for the year 2012-2014 from NRSC (National Remote Sensing Center) Hyderabad, which was preprocessed. Sentinel 2 data was downloaded from https:// usgsearthexplorer.usgs.gov for the year 2015 to 2021. Table 1 . Shows the data used in this study. The few important factors such as cloud cover, same seasonal data, uniform projection system etc. were considered for finalizing the satellite images. Band composition was done in ArcGIS 10.5 environment by using $10 \mathrm{~m}$ resolution bands (Blue, Green, Red and NIR). After that False Color Composition (FCC) was made by the combination of 4, 3, 2 (NIR, Red, Green) bands.

\section{Digitization of Shoreline}

The digital shoreline analysis system is a freely available software extension to ESRI ArcGIS that computes the rate of change of statistics from the historic shoreline. The DSAS uses the measurement baseline method to calculate the rate of change of statistics. Database was created to digitize the shoreline features. The shoreline features were defined using
Table 1. Data Used for Shoreline change

\begin{tabular}{lllllc}
\hline Data & Sensor & $\begin{array}{l}\text { Pixel } \\
\text { Depth }\end{array}$ & $\begin{array}{l}\text { Bands } \\
\text { used }\end{array}$ & $\begin{array}{l}\text { Resolu- } \\
\text { tion }\end{array}$ & Years \\
\hline Sentinel & MSI & 12 Bit & $\begin{array}{l}\text { Green, } \\
\text { Red, }\end{array}$ & & $2015-$ \\
2 & & & $\begin{array}{l}\text { Red } \\
\text { Blue, } \\
\text { and }\end{array}$ & & \\
& & & & \\
& & & NIR & & \\
LISS IV & L4FX & \multirow{2}{*}{16 Bit } & $\begin{array}{l}\text { Green } \\
\text { Red }\end{array}$ & $5.8 \mathrm{~m}$ & $2012-$ \\
& & & Red \\
& & & & 2014 \\
& & & NIR & & \\
\hline
\end{tabular}

the tonal differences between the land and sea. Band ratio was done to differentiate land and water. After that, vectorization technique was used in ArcGIS environment. Baseline was created by using some offset with shoreline. DSAS requires more than two shorelines and those must reside in a single features class. It also requires the features class should be in the meter unit in a projected coordinate system. A perpendicular transect was created by the help of DSAS at $100 \mathrm{~m}$ intervals from the baseline across the shoreline. However, a shorter interval of the transect can give more details rate of change estimation which reduces uncertainty but it is more time consuming and identification of erosion and accretion rate is very difficult. Therefore, $100 \mathrm{~m}$ interval transect is considered for this study. The uncertainty associated with the shoreline data capture, which has a significant effect on the positional accuracy of the shoreline extracted.

DSAS Tool provide 5 different measurements for rate of change calculation. These are NSM, SCE, EPR, LRR, and WLR. These 5 methods were calculated in this present study. Net Shoreline Movement (NSM) is not a rate measurement rather it's measures the distance in meter between the older and younger shoreline for each transect (Himmelstoss et al., 2018). Shoreline Change Envelop (SCE) is also measures the distance not a rate. SCE value refers the greatest distance within all the shorelines intersect in a particular transect. The End Point Rate (EPR) can be measured by dividing the NSM by the time elapsed between oldest and most recent shoreline. EPR is one of the computations which can computed with minimal requirement of only two shoreline dates (Himmelstoss et al., 2018).

NSM = Distance between Oldest and Youngest shorelines

$\mathrm{EPR}=\frac{N S M}{\text { Date } A-\text { date } B}$

Linear Regression Rate can be determined by the fitting a least-square regression line to all shoreline points in a transect (Himmelstoss et al., 2018). LRR derived from examining the associated $r$ squared value or friction of variance that is associated by the regression. Weighted Linear Regression measures the greater emphasis or weight to determine a best fit line. Greater weight has given on data point for the smaller position uncertainty. (Himmelstoss et al., 2018). The weight can be defined by following equation,

$w=1 / e^{2}$ 
Where, $\mathrm{e}$ is shoreline uncertainty value.

Uncertainty and R-squared Statistic

Uncertainty of End point Rate (EPRunc) is the uncertainty measurement for EPR. EPRunc can be calculated by following equation:

$$
\text { EPRunc }=\frac{\sqrt{(\text { uncy } A)^{2}+\left(\text { uncy } B^{2}\right.}}{\text { date } A-\text { date } B}
$$

Where, uncy $A=$ Uncertainty from attribute field of shoreline A,

uncy $B=$ Uncertainty from attribute field of shoreline $B$,

date $A$ = date of most recent shoreline, and

date $B$ = date of oldest shoreline.

\section{Standard error of Estimate}

Standard error of estimate generally calculated for accuracy of LRR and WLR methods. This is measure by predicted value of $y$ (distance from baseline) are computed by using value of $\mathrm{x}$ for the best fit line.

$$
y=m x+b
$$

Where, $y=$ predicted distance from baseline, $m=$ slope (the rate of change), and $b=y$-intercept.

$$
L S E \text { or } W S E=\sqrt{\frac{\Sigma\left(y-y^{\prime}\right)^{2}}{n-2}}
$$

Where, $\mathrm{y}=$ known distance from baseline for a shoreline data point,

$$
\begin{aligned}
& y^{t}=\text { predicted value based on equation, and } \mathrm{n}=\text { number of } \\
& \text { shorelines used. }
\end{aligned}
$$

\section{R-squared statistics}

R-square statistics is defined as LR2 for LRR and WR2 for WLR. Formula for R-square value

$$
R^{2}=1-\sqrt{\frac{\sum\left(y-y^{\prime}\right)^{2}}{\sum y-\text { mean of } y}}
$$

Where, ${ }^{R^{2}}=$ coefficient of determination,

$y=$ measured distance from baseline,

$y^{y^{\prime}}=$ predicted distance from baseline and mean of $y=$ mean value of measured shoreline distance from baseline.

\section{Kalman Filter Model for the forecast}

Kalman filter generally performs to minimize the position error between the modeled and observed shoreline to improve the forecast with the rates and uncertainties (Long and Plant, 2012). This model performs through the rate which is calculated by DSAS. This model was used in this present study to forecast the position of shoreline after 10 years.

\section{Result and Discussions}

The detection of shoreline changes along the Dahej coast of India's Gulf of Khambhat from 2012 to 2021 has been studied using data derived from multi-dated satellite images. The DSAS software was used to estimate the rate of shoreline changes and forecast shoreline position using the End Point Rate (EPR), Linear Regression Rate (LRR), and Weighted Linear Regression Rate (WLR) methods. There are five statistical measures have been calculated to identify the rate of change along the shoreline out of which three methods (EPR, LRR, WLR) for rate calculation and two method (SCE, NSM) for distance measurement. All the rate has been classified into 5 classes based on Table 2 .

Table 2. Criteria for shoreline change classification

\begin{tabular}{ll}
\hline EPR/LRR Values & Class \\
\hline$<-5$ & High erosion \\
-5 to -1 & Moderate erosion \\
-1 to 1 & Stable \\
$1-5$ & Moderate Accretion \\
$>5$ & High Accretion \\
\hline
\end{tabular}

Rate of change (2012-2021)

The Dahej coast has experienced both erosion and accretion, the northern part of the study area facing more accretion and southern part facing more erosion. Highest accretion rate as per the LRR method found $50 \mathrm{~m}$ at the transect 54, accretion rate at the same Transect is $38 \mathrm{~m}$ for EPR and accretion rate 51 for WLR method. The accretion mainly happened due to more vegetation cover in this region as compared to the southern part of the study area. The high erosion rate $-33 \mathrm{~m},-31 \mathrm{~m}$ and $-31 \mathrm{~m}$ in EPR, LRR and WLR respectively at the transect no 24 . The average rate of change (2.45m and $3.07 \mathrm{~m}$ by LRR and WLR method) falls under moderate accretion in this region. As the SCE measures the greatest distance among all shoreline, the value of SCE always positive. The highest SCE found 404 at transect 54. The highest negative NSM value found 296 and highest positive NSM found 347 at transect 54at a transect 24. The visual representation of rate of change (2012-2021) of all method are shown in Figure 3 to 6 and Figure 7 to 10 shows the bar diagram of rate of changes. Transect wise detail rate of change shown in Table 3. The erosion/accretion tendencies seen throughout this shoreline are the result of the combined action of waves and tides. Furthermore, because the coastal belt along the GOC is mostly made of clay sand or silt, coastal protection is problematic (Misra and Balaji, 2015). According to Misra and Balaji 2015 anthropogenic impacts are substantial in these places and have a significant impact on coastal processes. The shoreline is altered by a vast number of sea walls, groynes, breakwaters, and jetties, which disrupt the region's sediment dynamics (Gupta 2014; Mahapatra et al., 2014). Hence, The Dahej coast shoreline is changing at varying degrees of intensity. This is due to both natural and man-made activities. In the previous study (Misra and Balaji, 2015) they mostly focused on EPR and NSM methods which considers the first and last year data to measure the rates. In the present study we tried to calculate more effective result by using LRR and WLR methods in addition that considers initial to final, each year's data. So, the results could be more effective for predicting future trends and developing mitigation strategies. 


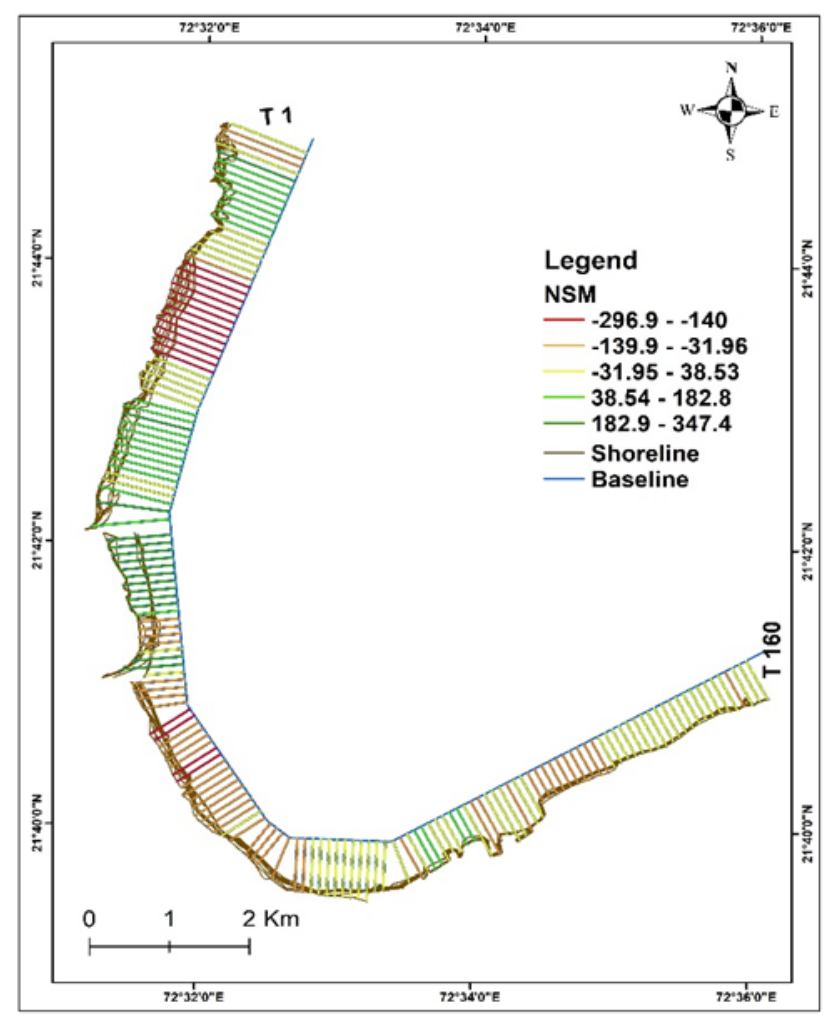

Figure 3. NSM map 2012-2021

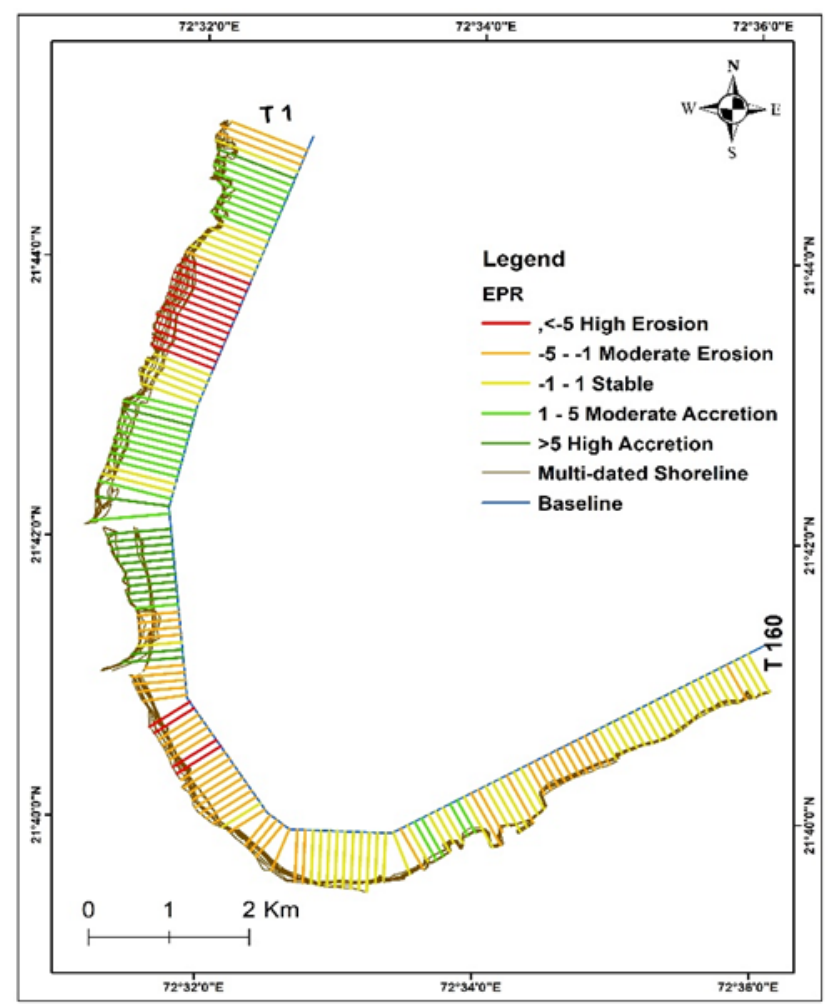

Figure 5. EPR Map 2012-2021

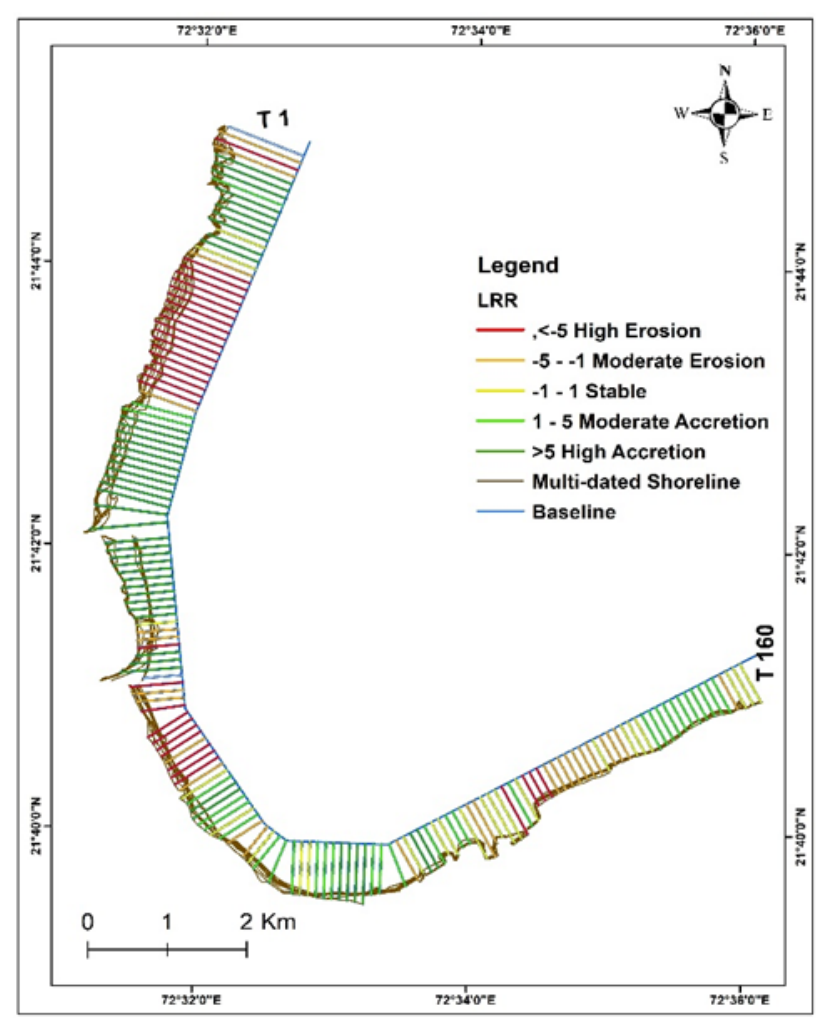

Figure 4. LRR Map 2012-2021

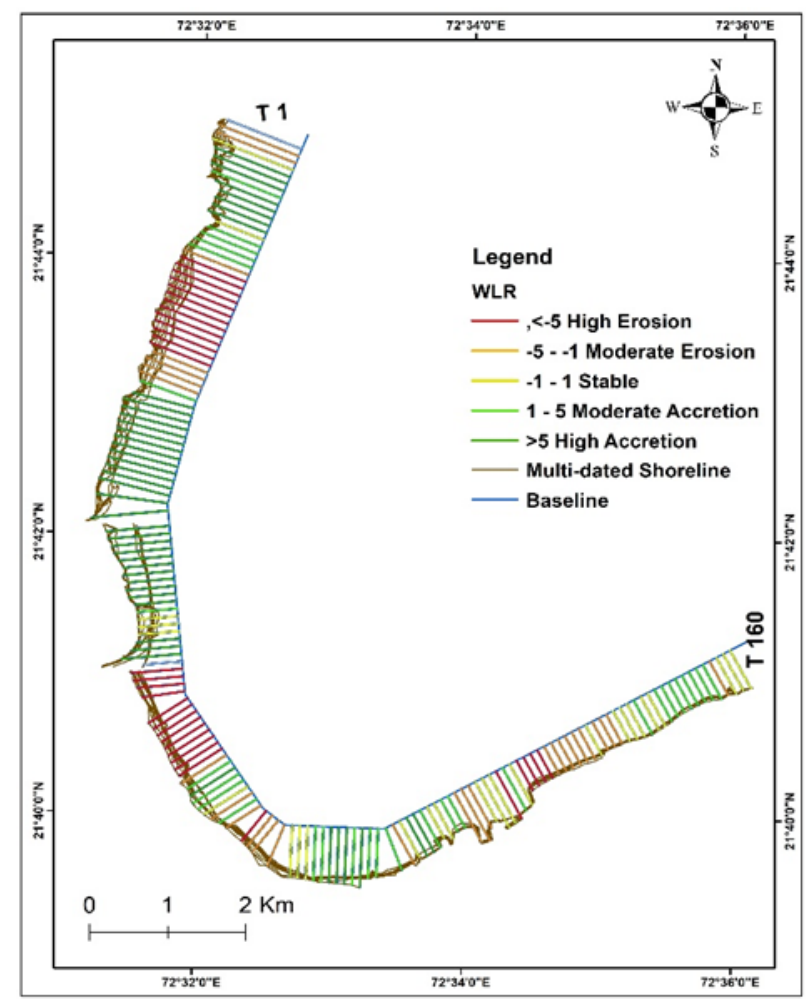

Figure 6. WLR Map 2021-2021 


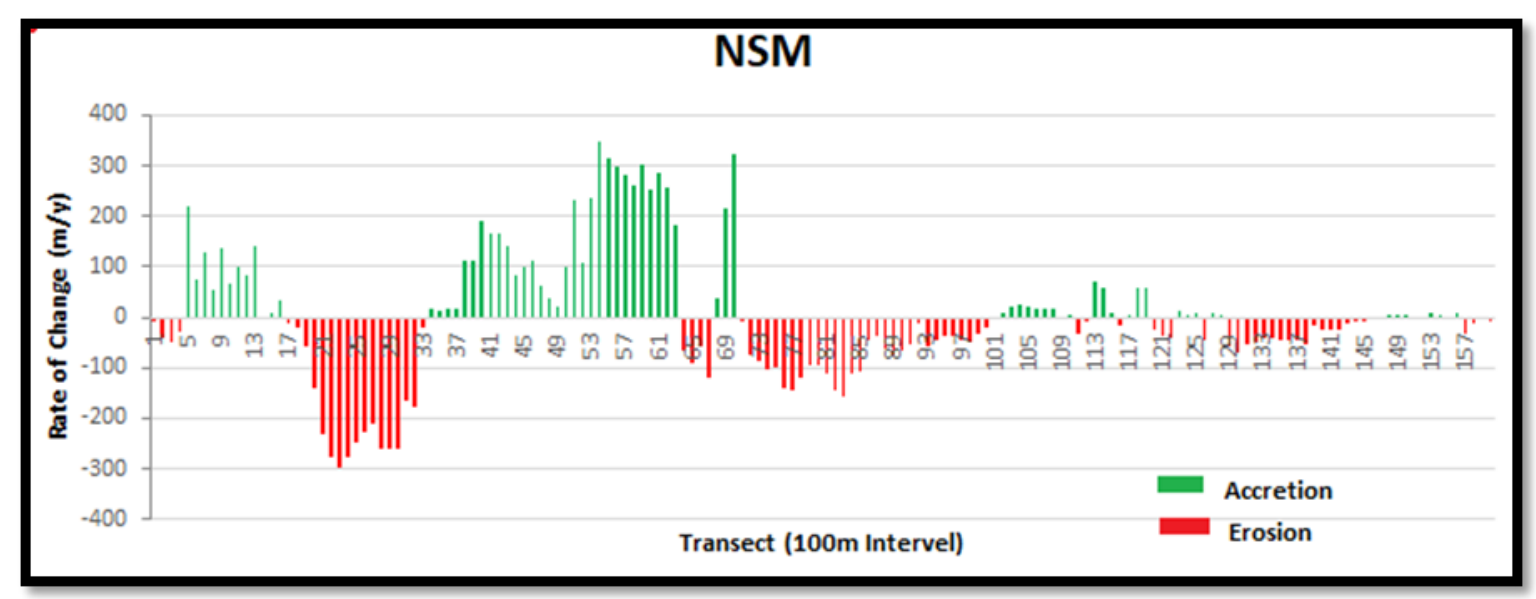

Figure 7. Bar diagram showing the NSM value.

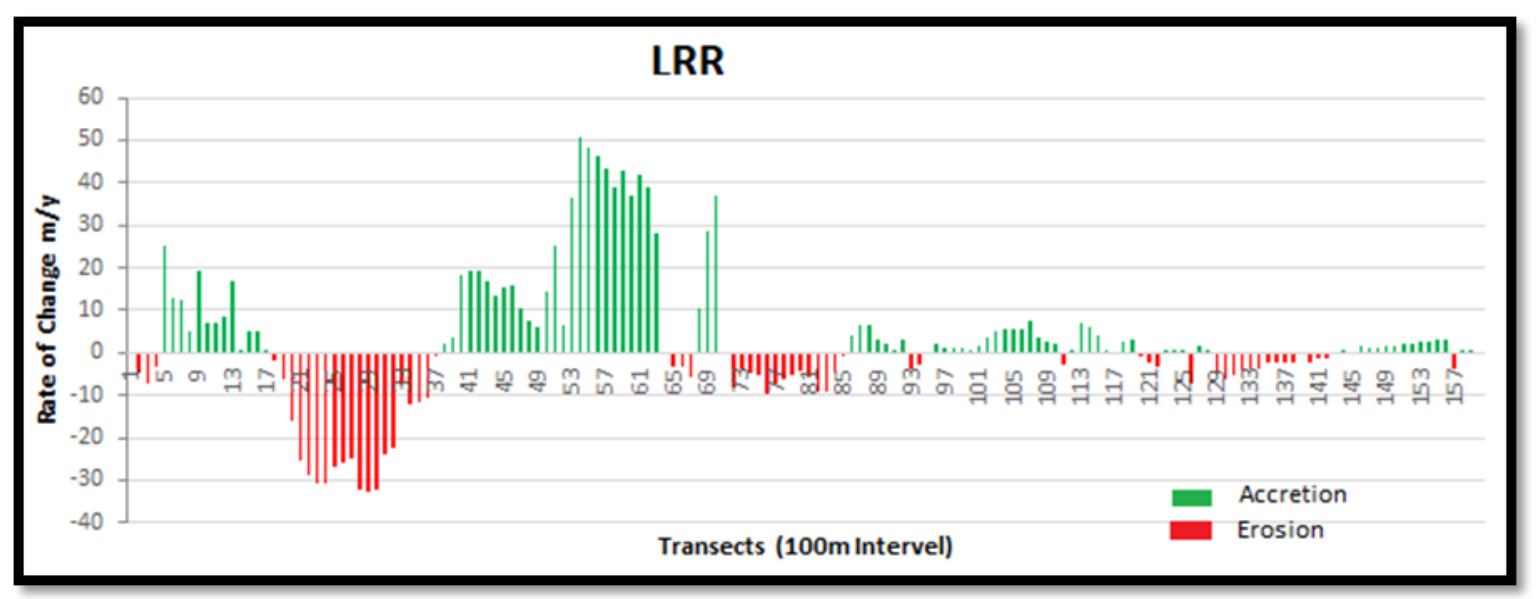

Figure 8. Bar diagram showing the LRR value

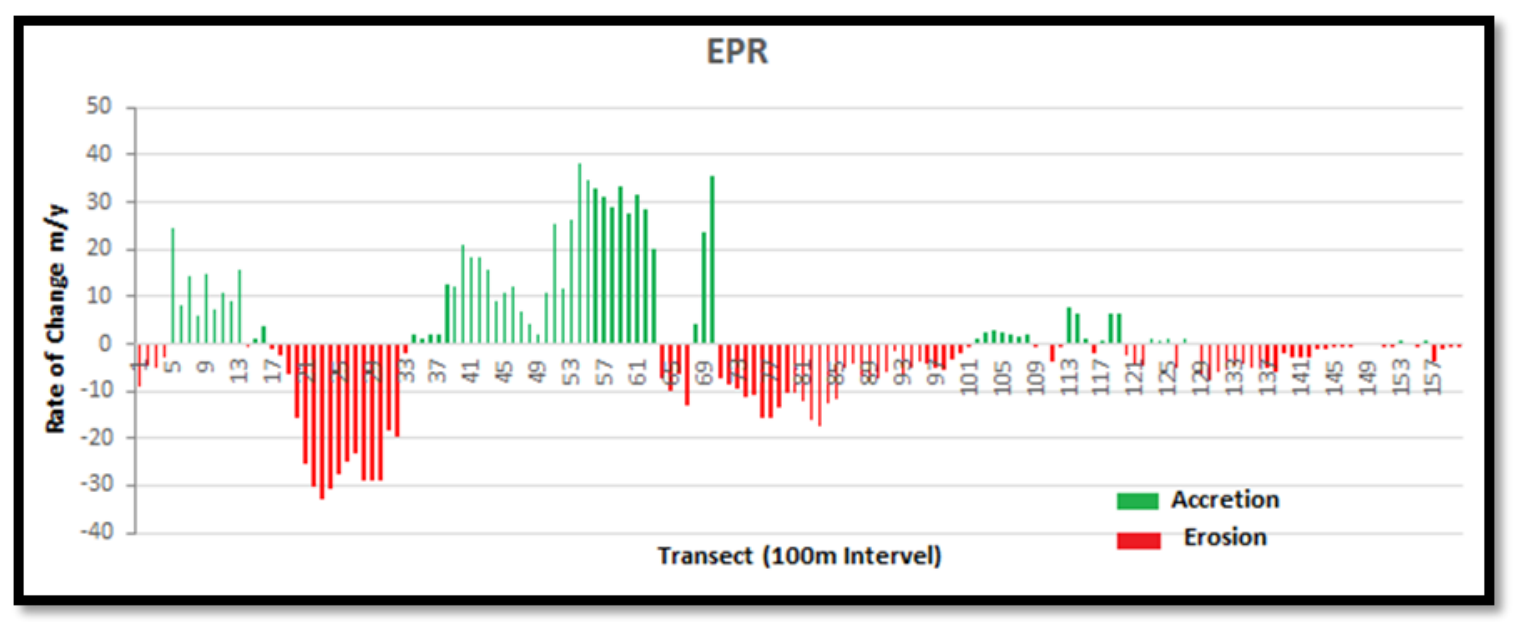

Figure 9. Bar diagram showing the EPR value 


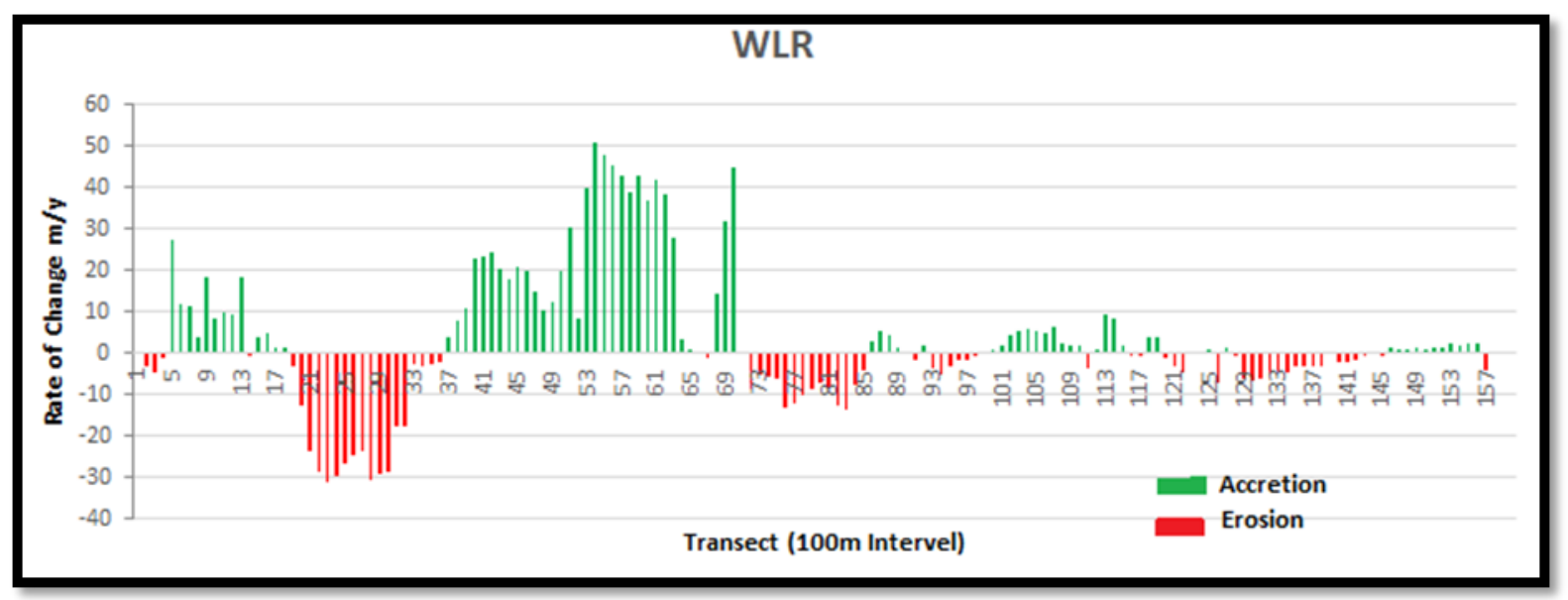

Figure 10. Bar diagram showing the WLR value.

Table 3. Transect wise details measurement.

\begin{tabular}{|c|c|c|c|c|c|c|c|c|c|c|}
\hline TransectID & SCE & NSM & EPR & EPRunc & LRR & LR2 & LSE & WLR & WR2 & WSE \\
\hline 1 & 9.6 & -9.6 & -9.08 & 6.69 & & & & & & \\
\hline 2 & 64.37 & -41.76 & -4.61 & 0.62 & -4.98 & 0.68 & 18.6 & -3.13 & 0.7 & 5.37 \\
\hline 3 & 122.65 & -47.83 & -5.28 & 0.62 & -7.37 & 0.62 & 31.57 & -4.84 & 0.63 & 7.72 \\
\hline 4 & 133.78 & -27.27 & -3.01 & 0.62 & -3.37 & 0.71 & 38.85 & -0.91 & 0.61 & 8.56 \\
\hline 5 & 238.17 & 220.29 & 24.33 & 0.62 & 25.12 & 0.71 & 51.23 & 27.46 & 0.78 & 12.42 \\
\hline 6 & 123.55 & 74.7 & 8.25 & 0.62 & 12.72 & 0.64 & 30.71 & 11.84 & 0.53 & 9.47 \\
\hline 7 & 145.43 & 129.73 & 14.33 & 0.62 & 12.57 & 0.66 & 28.79 & 11.47 & 0.59 & 8.22 \\
\hline 8 & 78.65 & 55.94 & 6.18 & 0.62 & 4.83 & 0.29 & 24.13 & 3.66 & 0.15 & 7.47 \\
\hline 9 & 162.73 & 134.61 & 14.87 & 0.62 & 19.15 & 0.82 & 28.75 & 18.5 & 0.78 & 8.5 \\
\hline 10 & 76.25 & 66.84 & 7.38 & 0.62 & 6.84 & 0.58 & 18.55 & 8.35 & 0.53 & 6.78 \\
\hline 11 & 107.26 & 99.96 & 11.04 & 0.62 & 7.15 & 0.45 & 25.09 & 9.66 & 0.45 & 9.05 \\
\hline 12 & 86.47 & 81.44 & 8.99 & 0.62 & 8.41 & 0.64 & 20.33 & 9.12 & 0.55 & 7.08 \\
\hline 13 & 150.68 & 141.22 & 15.6 & 0.62 & 16.7 & 0.9 & 17.79 & 18.13 & 0.92 & 4.44 \\
\hline 14 & 28.91 & -1.51 & -0.17 & 0.62 & 0.71 & 0.04 & 10.44 & -0.08 & 0 & 3.7 \\
\hline 15 & 73.34 & 8.74 & 0.97 & 0.62 & 5.25 & 0.65 & 20.36 & 3.7 & 0.7 & 7.08 \\
\hline 16 & 47.6 & 34.65 & 3.83 & 0.62 & 5.11 & 0.68 & 11.33 & 4.87 & 0.63 & 3.19 \\
\hline 17 & 55.52 & -10.61 & -1.17 & 0.62 & 0.39 & 0 & 21.96 & 1.33 & 0.05 & 4.91 \\
\hline 18 & 97.96 & -20.05 & -2.21 & 0.62 & -1.73 & 0.02 & 36.89 & 1.44 & 0.01 & 10.26 \\
\hline 19 & 105.34 & -58.41 & -6.45 & 0.62 & -6.14 & 0.68 & 32.53 & -2.93 & 0.62 & 9.08 \\
\hline 20 & 164.17 & -140 & -15.46 & 0.62 & -15.87 & 0.69 & 33.92 & -12.58 & 0.6 & 8.76 \\
\hline 21 & 230.46 & -230.46 & -25.45 & 0.62 & -25.39 & 0.95 & 18.74 & -23.49 & 0.93 & 5.31 \\
\hline 22 & 275.86 & -275.86 & -30.47 & 0.62 & -28.83 & 0.99 & 10.03 & -28.54 & 0.99 & 2.58 \\
\hline 23 & 296.9 & -296.9 & -32.79 & 0.62 & -30.81 & 0.99 & 12.05 & -30.96 & 0.98 & 3.82 \\
\hline 24 & 277.22 & -277.22 & -30.62 & 0.62 & -30.67 & 0.98 & 13.01 & -29.77 & 0.98 & 3.2 \\
\hline 25 & 249.82 & -249.82 & -27.59 & 0.62 & -26.72 & 0.99 & 8.55 & -26.67 & 0.99 & 2.75 \\
\hline 26 & 226.9 & -226.9 & -25.06 & 0.62 & -25.89 & 0.97 & 13.4 & -24.62 & 0.97 & 3.45 \\
\hline 27 & 210.72 & -210.72 & -23.27 & 0.62 & -25.01 & 0.96 & 15.79 & -23.5 & 0.94 & 4.88 \\
\hline 28 & 260.59 & -260.59 & -28.78 & 0.62 & -32.2 & 0.97 & 17.29 & -30.45 & 0.95 & 5.93 \\
\hline 29 & 261.21 & -260.09 & -28.72 & 0.62 & -32.85 & 0.92 & 31.07 & -29.4 & 0.85 & 10.7 \\
\hline
\end{tabular}




\begin{tabular}{|c|c|c|c|c|c|c|c|c|c|c|}
\hline 30 & 269.83 & -261.68 & -28.9 & 0.62 & -32.31 & 0.91 & 32.76 & -28.61 & 0.85 & 10.17 \\
\hline 31 & 240.5 & -164.58 & -18.18 & 0.62 & -23.7 & 0.68 & 52.43 & -17.61 & 0.45 & 16.59 \\
\hline 32 & 216.64 & -179.4 & -19.81 & 0.62 & -22.42 & 0.77 & 39.2 & -17.83 & 0.6 & 12.44 \\
\hline 33 & 149.84 & -19.78 & -2.18 & 0.62 & -7.31 & 0.65 & 52.37 & -2.61 & 0.7 & 16.63 \\
\hline 34 & 235.4 & 17.63 & 1.95 & 0.62 & -11.89 & 0.72 & 86.25 & -3.28 & 0.64 & 30.7 \\
\hline 35 & 217.23 & 10.56 & 1.17 & 0.62 & -11.69 & 0.73 & 84.93 & -2.72 & 0.71 & 29.44 \\
\hline 36 & 212.8 & 18.21 & 2.01 & 0.62 & -10.56 & 0.69 & 77.5 & -2.39 & 0.7 & 27.26 \\
\hline 37 & 144.18 & 16.46 & 1.82 & 0.62 & -1.05 & 0 & 52.22 & 3.68 & 0.04 & 15.28 \\
\hline 38 & 189.3 & 112.65 & 12.44 & 0.62 & 2.03 & 0.01 & 59.32 & 8.06 & 0.09 & 21.47 \\
\hline 39 & 197.96 & 111.03 & 12.26 & 0.62 & 3.66 & 0.62 & 64.62 & 10.88 & 0.71 & 21.52 \\
\hline 40 & 202.68 & 190.4 & 21.03 & 0.62 & 18.17 & 0.6 & 47.34 & 22.93 & 0.64 & 14.61 \\
\hline 41 & 171.23 & 165.88 & 18.32 & 0.62 & 19.47 & 0.69 & 41.87 & 23.26 & 0.77 & 10.87 \\
\hline 42 & 193.5 & 166.03 & 18.34 & 0.62 & 19.09 & 0.54 & 56.04 & 24.35 & 0.62 & 16.15 \\
\hline 43 & 165.64 & 142.3 & 15.72 & 0.62 & 16.83 & 0.63 & 41.36 & 20.45 & 0.76 & 9.81 \\
\hline 44 & 174.97 & 81.91 & 9.05 & 0.62 & 13.35 & 0.71 & 57.48 & 17.91 & 0.55 & 13.84 \\
\hline 45 & 186.92 & 99.78 & 11.02 & 0.62 & 15.22 & 0.68 & 62.83 & 20.85 & 0.54 & 16.54 \\
\hline 46 & 166 & 111.69 & 12.34 & 0.62 & 15.99 & 0.63 & 45.2 & 20.04 & 0.7 & 11.23 \\
\hline 47 & 152.8 & 62.8 & 6.94 & 0.62 & 10.52 & 0.72 & 55.4 & 14.8 & 0.68 & 12.49 \\
\hline 48 & 147.43 & 38.53 & 4.26 & 0.62 & 7.32 & 0.7 & 55 & 10.4 & 0.72 & 11.68 \\
\hline 49 & 156.38 & 19.93 & 2.2 & 0.62 & 6.25 & 0.07 & 73.33 & 12.31 & 0.26 & 17.97 \\
\hline 50 & 175.35 & 100 & 11.04 & 0.62 & 14.44 & 0.75 & 63.44 & 20.04 & 0.66 & 17.51 \\
\hline 51 & 232.86 & 231.65 & 25.58 & 0.62 & 24.98 & 0.71 & 51.17 & 30.18 & 0.76 & 14.64 \\
\hline 52 & 106.31 & 106.31 & 11.74 & 0.62 & 6.56 & 0.61 & 24.38 & 8.15 & 0.64 & 8.59 \\
\hline 53 & 399.22 & 237.59 & 26.24 & 0.62 & 36.45 & 0.68 & 121.45 & 39.9 & 0.58 & 28.76 \\
\hline 54 & 404.44 & 347.44 & 38.37 & 0.62 & 50.46 & 0.66 & 115.13 & 51.01 & 0.67 & 30.76 \\
\hline 55 & 384.95 & 315.26 & 34.82 & 0.62 & 48.47 & 0.64 & 115.97 & 48.01 & 0.61 & 32.56 \\
\hline 56 & 360.18 & 297.88 & 32.9 & 0.62 & 46.19 & 0.67 & 102.98 & 45.34 & 0.63 & 29.61 \\
\hline 57 & 324.35 & 282.26 & 31.17 & 0.62 & 43.28 & 0.7 & 91.45 & 42.69 & 0.66 & 26.09 \\
\hline 58 & 292.29 & 260.43 & 28.76 & 0.62 & 39.14 & 0.7 & 82.61 & 38.82 & 0.67 & 23.24 \\
\hline 59 & 319.42 & 301.18 & 33.26 & 0.62 & 42.93 & 0.73 & 84.31 & 42.65 & 0.71 & 23.51 \\
\hline 60 & 275.5 & 250.81 & 27.7 & 0.62 & 37.06 & 0.71 & 76.51 & 36.95 & 0.69 & 21.25 \\
\hline 61 & 312.5 & 285.77 & 31.56 & 0.62 & 41.69 & 0.71 & 85.29 & 41.62 & 0.7 & 23.57 \\
\hline 62 & 293.55 & 257.24 & 28.41 & 0.62 & 38.67 & 0.7 & 80.62 & 38.37 & 0.68 & 22.67 \\
\hline 63 & 229.66 & 182.78 & 20.19 & 0.62 & 28.12 & 0.65 & 65.96 & 27.61 & 0.61 & 18.94 \\
\hline 64 & 240.83 & -67.03 & -7.4 & 0.62 & -0.17 & 0 & 101.42 & 3.33 & 0.02 & 21.88 \\
\hline 65 & 264.01 & -91.74 & -10.13 & 0.62 & -3.07 & 0.01 & 99.31 & 0.66 & 0 & 21.25 \\
\hline 66 & 224.84 & -59.29 & -6.55 & 0.62 & -3.54 & 0.02 & 84.98 & 0.38 & 0 & 18.35 \\
\hline 67 & 237.1 & -117.91 & -13.02 & 0.62 & -5.61 & 0.05 & 81.34 & -0.91 & 0 & 17.81 \\
\hline 68 & 178.64 & 36.61 & 4.04 & 0.62 & 10.51 & 0.72 & 62.4 & 14.42 & 0.8 & 15.77 \\
\hline 69 & 241.87 & 213.51 & 23.58 & 0.62 & 28.71 & 0.8 & 46.38 & 31.95 & 0.79 & 14.06 \\
\hline 70 & 341.2 & 320.7 & 35.42 & 0.62 & 36.92 & 0.7 & 77.62 & 45.05 & 0.7 & 25.42 \\
\hline 71 & 7.5 & -7.5 & -7.15 & 3.37 & & & & & & \\
\hline 72 & 118.98 & -76.04 & -8.4 & 0.62 & -8.1 & 0.69 & 39.44 & -8.81 & 0.62 & 14.9 \\
\hline 73 & 139.93 & -86.84 & -9.59 & 0.62 & -3.95 & 0.73 & 48.51 & -5 & 0.66 & 14.84 \\
\hline 74 & 142.84 & -102.46 & -11.32 & 0.62 & -4.86 & 0.68 & 50.35 & -5.77 & 0.7 & 15.27 \\
\hline 75 & 121.47 & -98.32 & -10.86 & 0.62 & -5.49 & 0.76 & 46.39 & -6.21 & 0.77 & 13.68 \\
\hline
\end{tabular}




\begin{tabular}{|c|c|c|c|c|c|c|c|c|c|c|}
\hline 76 & 172.15 & -140.33 & -15.5 & 0.62 & -9.51 & 0.81 & 46.61 & -13.35 & 0.6 & 15.08 \\
\hline 77 & 159.28 & -142.47 & -15.73 & 0.62 & -7.39 & 0.53 & 55.16 & -11.92 & 0.6 & 16.99 \\
\hline 78 & 131.06 & -120.2 & -13.27 & 0.62 & -6.31 & 0.59 & 41.61 & -10 & 0.63 & 14.09 \\
\hline 79 & 121.22 & -94.4 & -10.43 & 0.62 & -5.25 & 0.6 & 35.8 & -8.71 & 0.65 & 12.48 \\
\hline 80 & 109.22 & -93.5 & -10.33 & 0.62 & -4.38 & 0.78 & 35.22 & -7.27 & 0.78 & 11.91 \\
\hline 81 & 125.05 & -111.94 & -12.36 & 0.62 & -5.65 & 0.67 & 37.65 & -8.22 & 0.66 & 12.79 \\
\hline 82 & 144.15 & -144.15 & -15.92 & 0.62 & -9.33 & 0.69 & 36.36 & -12.42 & 0.61 & 12.65 \\
\hline 83 & 165.07 & -157.53 & -17.4 & 0.62 & -9.26 & 0.59 & 49.5 & -13.79 & 0.67 & 17.31 \\
\hline 84 & 132.65 & -112.76 & -12.45 & 0.62 & -4.67 & 0.14 & 37 & -7.72 & 0.18 & 14.18 \\
\hline 85 & 154.38 & -107.53 & -11.88 & 0.62 & -0.88 & 0 & 46.92 & -4.39 & 0.04 & 17.93 \\
\hline 86 & 126.63 & -46.09 & -5.09 & 0.62 & 4.29 & 0.1 & 41.28 & 2.63 & 0.02 & 15.61 \\
\hline 87 & 153.95 & -36.46 & -4.03 & 0.62 & 6.38 & 0.15 & 49.41 & 5.18 & 0.05 & 18.81 \\
\hline 88 & 189.41 & -62.5 & -6.9 & 0.62 & 6.33 & 0.1 & 59.89 & 4.45 & 0.03 & 23.45 \\
\hline 89 & 169.5 & -73.05 & -8.07 & 0.62 & 3.29 & 0.04 & 50.39 & 1.14 & 0 & 19.74 \\
\hline 90 & 136.16 & -65.31 & -7.21 & 0.62 & 2.08 & 0.03 & 40.96 & 0.11 & 0 & 15.98 \\
\hline 91 & 90.34 & -54.24 & -5.99 & 0.62 & 0.22 & 0 & 28.47 & -1.75 & 0.02 & 10.95 \\
\hline 92 & 50.63 & -12.06 & -1.33 & 0.62 & 2.85 & 0.21 & 17.61 & 1.77 & 0.05 & 6.54 \\
\hline 93 & 59.59 & -59.59 & -6.58 & 0.62 & -3.59 & 0.34 & 15.93 & -3.62 & 0.21 & 6.01 \\
\hline 94 & 98.23 & -47.05 & -5.2 & 0.62 & -2.76 & 0.09 & 28.73 & -5.04 & 0.2 & 8.7 \\
\hline 95 & 104.31 & -35.84 & -3.96 & 0.62 & -0.45 & 0 & 38 & -3.29 & 0.06 & 11.58 \\
\hline 96 & 119.45 & -38.06 & -4.2 & 0.62 & 1.96 & 0.02 & 45.75 & -1.55 & 0.01 & 14.14 \\
\hline 97 & 118.61 & -45.19 & -4.99 & 0.62 & 1.34 & 0.01 & 41.01 & -1.64 & 0.01 & 13.58 \\
\hline 98 & 103.62 & -48.76 & -5.38 & 0.62 & 1.31 & 0.02 & 32.86 & -0.49 & 0 & 12.26 \\
\hline 99 & 72.66 & -31.96 & -3.53 & 0.62 & 1 & 0.02 & 23.74 & 0.46 & 0 & 9.06 \\
\hline 100 & 48.21 & -19.02 & -2.1 & 0.62 & 0.87 & 0.02 & 18.84 & 0.75 & 0.01 & 6.31 \\
\hline 101 & 42.38 & -5.02 & -0.55 & 0.62 & 1.47 & 0.11 & 13.68 & 1.84 & 0.17 & 3.46 \\
\hline 102 & 67.79 & 9.91 & 1.09 & 0.62 & 3.42 & 0.18 & 22.94 & 4.15 & 0.35 & 4.82 \\
\hline 103 & 82.09 & 21.89 & 2.42 & 0.62 & 4.97 & 0.28 & 25.65 & 5.47 & 0.44 & 5.3 \\
\hline 104 & 92.71 & 24.42 & 2.7 & 0.62 & 5.51 & 0.3 & 26.76 & 5.76 & 0.44 & 5.52 \\
\hline 105 & 95.77 & 21.16 & 2.34 & 0.62 & 5.64 & 0.33 & 25.41 & 5.43 & 0.43 & 5.36 \\
\hline 106 & 112.13 & 16.31 & 1.8 & 0.62 & 5.66 & 0.27 & 29.86 & 4.97 & 0.31 & 6.33 \\
\hline 107 & 147.27 & 15.74 & 1.74 & 0.62 & 7.5 & 0.27 & 39.26 & 6.14 & 0.28 & 8.34 \\
\hline 108 & 49.87 & 17.7 & 1.95 & 0.62 & 3.8 & 0.39 & 15.14 & 2.44 & 0.16 & 4.8 \\
\hline 109 & 36.97 & -3.04 & -0.34 & 0.62 & 2.62 & 0.3 & 12.91 & 1.87 & 0.1 & 4.82 \\
\hline 110 & 55.89 & 0.84 & 0.09 & 0.62 & 2.19 & 0.11 & 20.09 & 1.81 & 0.05 & 6.67 \\
\hline 111 & 51.46 & -32.19 & -3.55 & 0.62 & -2.89 & 0.23 & 16.69 & -3.5 & 0.19 & 6.25 \\
\hline 112 & 46.73 & -7.1 & -0.78 & 0.62 & 0.66 & 0.01 & 17.51 & 0.84 & 0.03 & 4.29 \\
\hline 113 & 76.42 & 70.48 & 7.78 & 0.62 & 7.12 & 0.51 & 22.33 & 9.45 & 0.52 & 7.75 \\
\hline 114 & 69.09 & 58.69 & 6.48 & 0.62 & 6.22 & 0.53 & 18.8 & 8.18 & 0.56 & 6.25 \\
\hline 115 & 130.14 & 9.63 & 1.06 & 0.62 & 3.87 & 0.08 & 43.09 & 2 & 0.01 & 15.69 \\
\hline 116 & 42.75 & -17.47 & -1.93 & 0.62 & 0.49 & 0.01 & 14.27 & -0.45 & 0.01 & 5.2 \\
\hline 117 & 22.53 & 5.66 & 0.63 & 0.62 & -0.01 & 0 & 8.33 & -0.49 & 0.05 & 1.78 \\
\hline 118 & 63.41 & 59.37 & 6.56 & 0.62 & 2.76 & 0.22 & 16.74 & 3.78 & 0.2 & 6.41 \\
\hline 119 & 64.91 & 59.81 & 6.61 & 0.62 & 3.09 & 0.26 & 16.7 & 4.06 & 0.23 & 6.34 \\
\hline 120 & 22.99 & -22.99 & -2.54 & 0.62 & -0.69 & 0.09 & 6.93 & -1.17 & 0.17 & 2.23 \\
\hline 121 & 49.01 & -37.53 & -4.14 & 0.62 & -2.4 & 0.25 & 13.29 & -3.26 & 0.43 & 3.18 \\
\hline
\end{tabular}




\begin{tabular}{|c|c|c|c|c|c|c|c|c|c|c|}
\hline 122 & 85.09 & -41.37 & -4.57 & 0.62 & -3.07 & 0.18 & 21.25 & -4.52 & 0.29 & 6.07 \\
\hline 123 & 16.38 & 11.78 & 1.3 & 0.62 & 0.8 & 0.26 & 4.26 & 0.53 & 0.12 & 1.24 \\
\hline 124 & 8.36 & 6.01 & 0.66 & 0.62 & 0.55 & 0.29 & 2.73 & 0.56 & 0.36 & 0.63 \\
\hline 125 & 9.36 & 9.36 & 1.03 & 0.62 & 0.78 & 0.67 & 1.73 & 0.83 & 0.64 & 0.53 \\
\hline 126 & 58.57 & -45.47 & -5.02 & 0.62 & -7.06 & 0.62 & 17.83 & -7.31 & 0.65 & 4.56 \\
\hline 127 & 17.71 & 10.36 & 1.14 & 0.62 & 1.5 & 0.7 & 3.1 & 1.55 & 0.63 & 1.02 \\
\hline 128 & 21.28 & 0.66 & 0.07 & 0.62 & 0.32 & 0.02 & 7.57 & -0.43 & 0.03 & 2.09 \\
\hline 129 & 78.47 & -57.47 & -6.35 & 0.62 & -5.1 & 0.53 & 15.41 & -6.04 & 0.52 & 4.96 \\
\hline 130 & 87.73 & -68.83 & -7.6 & 0.62 & -6.02 & 0.62 & 15.17 & -6.73 & 0.68 & 3.94 \\
\hline 131 & 77.99 & -52.32 & -5.78 & 0.62 & -5.26 & 0.6 & 13.65 & -6.03 & 0.72 & 3.25 \\
\hline 132 & 58.93 & -48.97 & -5.41 & 0.62 & -4.52 & 0.67 & 10.25 & -5.36 & 0.71 & 2.91 \\
\hline 133 & 52.52 & -41.89 & -4.63 & 0.62 & -3.94 & 0.56 & 11.2 & -4.84 & 0.54 & 3.81 \\
\hline 134 & 53.17 & -39.14 & -4.32 & 0.62 & -3.98 & 0.53 & 12.02 & -4.79 & 0.51 & 4.02 \\
\hline 135 & 63.69 & -44.43 & -4.91 & 0.62 & -2.28 & 0.15 & 17.59 & -3.1 & 0.14 & 6.55 \\
\hline 136 & 64.68 & -44.15 & -4.88 & 0.62 & -2.21 & 0.14 & 17.5 & -3.04 & 0.14 & 6.41 \\
\hline 137 & 65.48 & -46.53 & -5.14 & 0.62 & -2.23 & 0.14 & 17.48 & -3.25 & 0.16 & 6.4 \\
\hline 138 & 63.76 & -52.63 & -5.81 & 0.62 & -2.1 & 0.12 & 18.4 & -3.28 & 0.14 & 6.94 \\
\hline 139 & 30.11 & -16.52 & -1.82 & 0.62 & 0 & 0 & 12.23 & 0.06 & 0 & 4.18 \\
\hline 140 & 30.22 & -25.81 & -2.85 & 0.62 & -2.11 & 0.58 & 5.73 & -2.28 & 0.52 & 1.86 \\
\hline 141 & 29.91 & -24.65 & -2.72 & 0.62 & -1.53 & 0.29 & 7.67 & -2.03 & 0.38 & 2.24 \\
\hline 142 & 25.92 & -23.96 & -2.65 & 0.62 & -1.2 & 0.18 & 8.25 & -1.6 & 0.28 & 2.21 \\
\hline 143 & 20.65 & -11.04 & -1.22 & 0.62 & -0.59 & 0.07 & 6.96 & -0.64 & 0.1 & 1.69 \\
\hline 144 & 23.63 & -9.4 & -1.04 & 0.62 & 0.01 & 0 & 7.49 & 0.09 & 0 & 1.58 \\
\hline 145 & 21.31 & -7.17 & -0.79 & 0.62 & -0.33 & 0.02 & 8.07 & -0.36 & 0.03 & 1.9 \\
\hline 146 & 30.54 & -2.81 & -0.31 & 0.62 & 1.41 & 0.13 & 11.7 & 1.38 & 0.18 & 2.53 \\
\hline 147 & 32.16 & -1.85 & -0.2 & 0.62 & 1.09 & 0.81 & 9.35 & 0.89 & 0.8 & 2.13 \\
\hline 148 & 36.03 & 1.7 & 0.19 & 0.62 & 1.21 & 0.76 & 11.09 & 0.8 & 0.77 & 2.71 \\
\hline 149 & 32.49 & 2.88 & 0.32 & 0.62 & 1.52 & 0.8 & 8.87 & 1.22 & 0.77 & 1.97 \\
\hline 150 & 30.08 & 1.03 & 0.11 & 0.62 & 1.5 & 0.71 & 8.87 & 1.04 & 0.72 & 2.06 \\
\hline 151 & 44.96 & -2.81 & -0.31 & 0.62 & 1.93 & 0.84 & 12.75 & 1.19 & 0.82 & 3.27 \\
\hline 152 & 40.51 & -1.64 & -0.18 & 0.62 & 1.92 & 0.81 & 10.17 & 1.51 & 0.8 & 2.48 \\
\hline 153 & 38.71 & 7.81 & 0.86 & 0.62 & 2.75 & 0.83 & 7.95 & 2.4 & 0.81 & 2.14 \\
\hline 154 & 56.12 & 1.76 & 0.19 & 0.62 & 2.45 & 0.8 & 15.61 & 1.71 & 0.79 & 4.42 \\
\hline 155 & 64.23 & -2.17 & -0.24 & 0.62 & 3.19 & 0.79 & 15.2 & 2.31 & 0.77 & 4.73 \\
\hline 156 & 42.38 & 7.4 & 0.82 & 0.62 & 2.96 & 0.76 & 8.84 & 2.5 & 0.78 & 2.66 \\
\hline 157 & 43.36 & -33.97 & -3.75 & 0.62 & -3.63 & 0.78 & 8.66 & -4.13 & 0.8 & 2.07 \\
\hline 158 & 23.11 & -10.47 & -1.16 & 0.62 & 0.39 & 0.83 & 7.44 & 0.15 & 0.81 & 2.36 \\
\hline 159 & 22.15 & -2.37 & -0.26 & 0.62 & 0.42 & 0.8 & 6.39 & 0.56 & 0.79 & 2.31 \\
\hline 160 & 17.97 & -6.6 & -0.73 & 0.62 & -0.04 & 0.81 & 6.56 & 0.19 & 0.76 & 1.42 \\
\hline
\end{tabular}

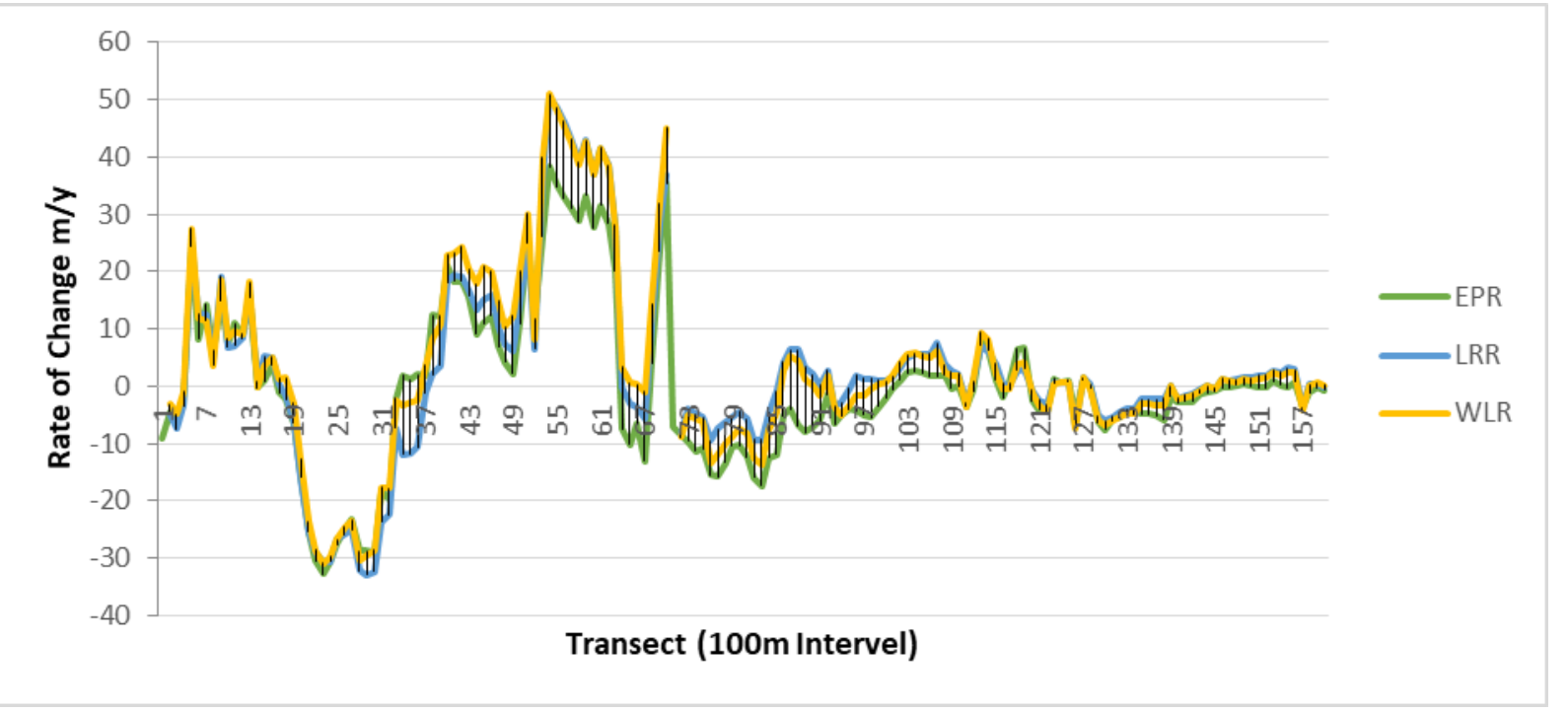

Figure 11. Line Graph shows the differences of rate in different methods. 
Table: 4. Percentage of erosion and accretion.

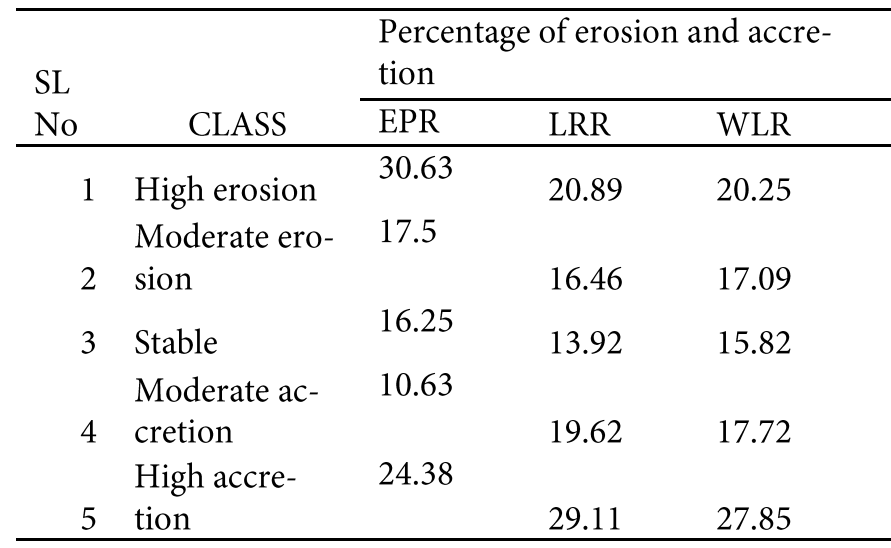

Comparative study among EPR, LRR and WLR

A comparative study has been carried out within three different rate measurement. All the rate of shoreline change has been classified into 5 categories based on Table 2. The comparison rate of shoreline changes computed using the EPR, LRR and WLR is presented in Table 4. It is evident from the table that percentage rates obtained from the three methods, whining which result of LRR and WLR are very similar and result of EPR little varies from LRR and WLR. The main causes behind this variation are in case of EPR calculation it does not use all the multi-dated data rather it measures through oldest and youngest data on the other side LRR and WLR used all the data in attribute table. A comparative line graph of EPR, LRR and WLR shown in Figure 11.

Although, there are some variations found in three methods of rate calculation but these methods are highly correlated to each other. To finalize the comparative study of these three methods we have derived a linear regression model for the parameters in a single frame with two different regression line. Here we have considered EPR value is an independent variable and LRR, WLR are considered as dependent variables. The R-square values were 0.91 and 0.94 in LRR and WLR respectively. Figure 12. Shows the Linear Regression Model for EPR, LRR and WLR.

\section{Uncertainty and Accuracy Measurements}

The $10 \mathrm{~m}$ uncertainty was considered in this study. Finally, Uncertainty of EPR (EPRunc) 0.62 for all the transects were generated by using the Equation 3. To calculate the accuracy of LRR and WLR R-Square statistics was applied and Standard error of estimation also measured for these two rates. Table 3. Shows the transect wise rate of change and their accuracy and standard error of estimation values. LR2 and WR2 indicates the R-square value of LRR and WLR. LSE and WSE denotes the standard error of LRR and WLR respectively. $\mathrm{R}$-square values have been categories into 4 classes $\left(\mathrm{R}^{2}>0.6\right.$ High accuracy, $\mathrm{R}^{2}=0.4-0.6$ Moderate accuracy, $\mathrm{R}^{2}<0.4$ is less accuracy and 0 value of $\mathrm{R}^{2}$ represents no relationship between variables. In LRR method, $57 \%$ data falls under and 55\% in WLR method. There are 14\% data has been found with $0 \mathrm{R}$-square value. Table 5 . Shows the classification of $\mathrm{R}^{2}$ values and their percentage.

Shoreline forecasting using Kalman filter method

Based on the previous 10 years data and their rate of change statistics we forecast the future shoreline position. In this present study 2012-2021 (10 years) data was used to predict the position of shoreline after 10 years therefore, the year of 2031 shoreline position has been predicted in this region using DSAS tool in ArcGIS 10.5 environment. The result shows in line features for shoreline position and

Table 5. Zone wise shoreline change analysis along Dahej Coast.

\begin{tabular}{lllll}
\hline CLASS & LR2 Count & Percentage & WR2 Count & Percentage \\
\hline HIGH ACCURACY (R2=>0.6) & 90 & 56.96 & 87 & 55.06 \\
MODERATE ACCURACY & & & & \\
(R2= 0.4-0.6) & 5 & 3.16 & 14 & 8.86 \\
LESS ACCURACY R2=0.1-0.4) & 41 & 25.94 & 31 & 19.62 \\
NO RELATION (R2=0) & 22 & 13.92 & 26 & 13.92 \\
\hline
\end{tabular}

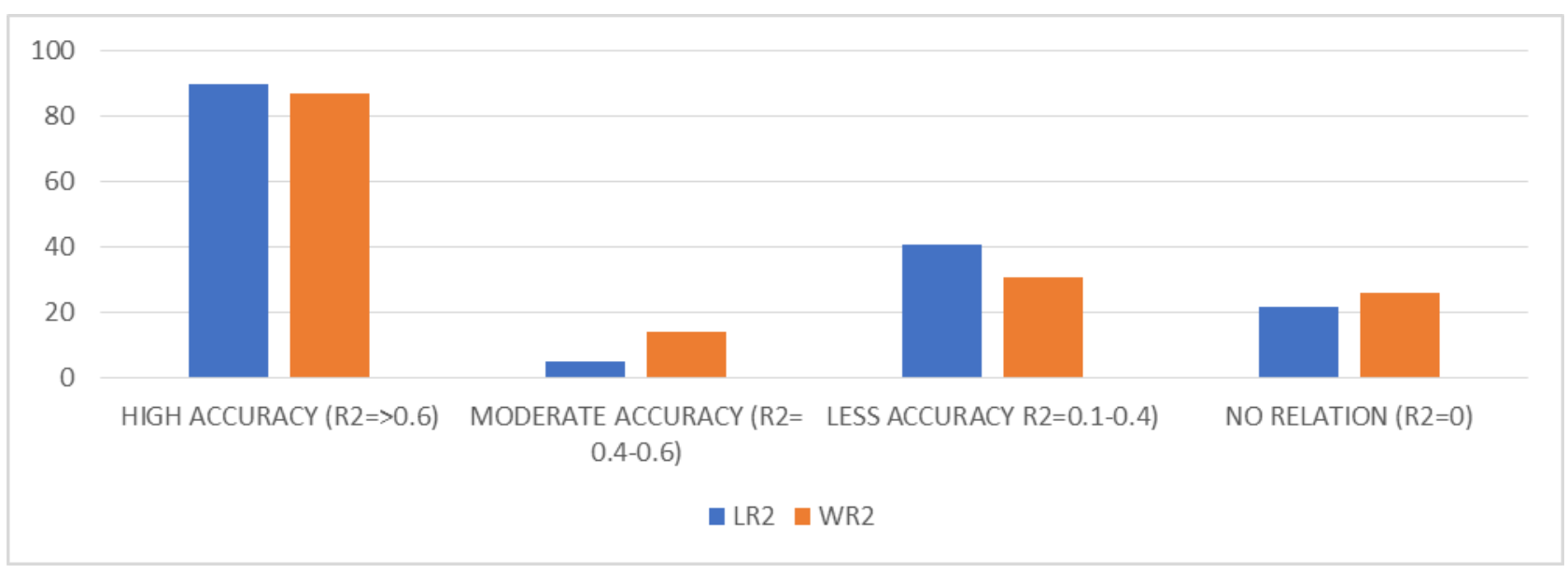

Figure 13. Bar diagram shows visual representation of $\mathrm{R}^{2}$ statistics of two methods. 


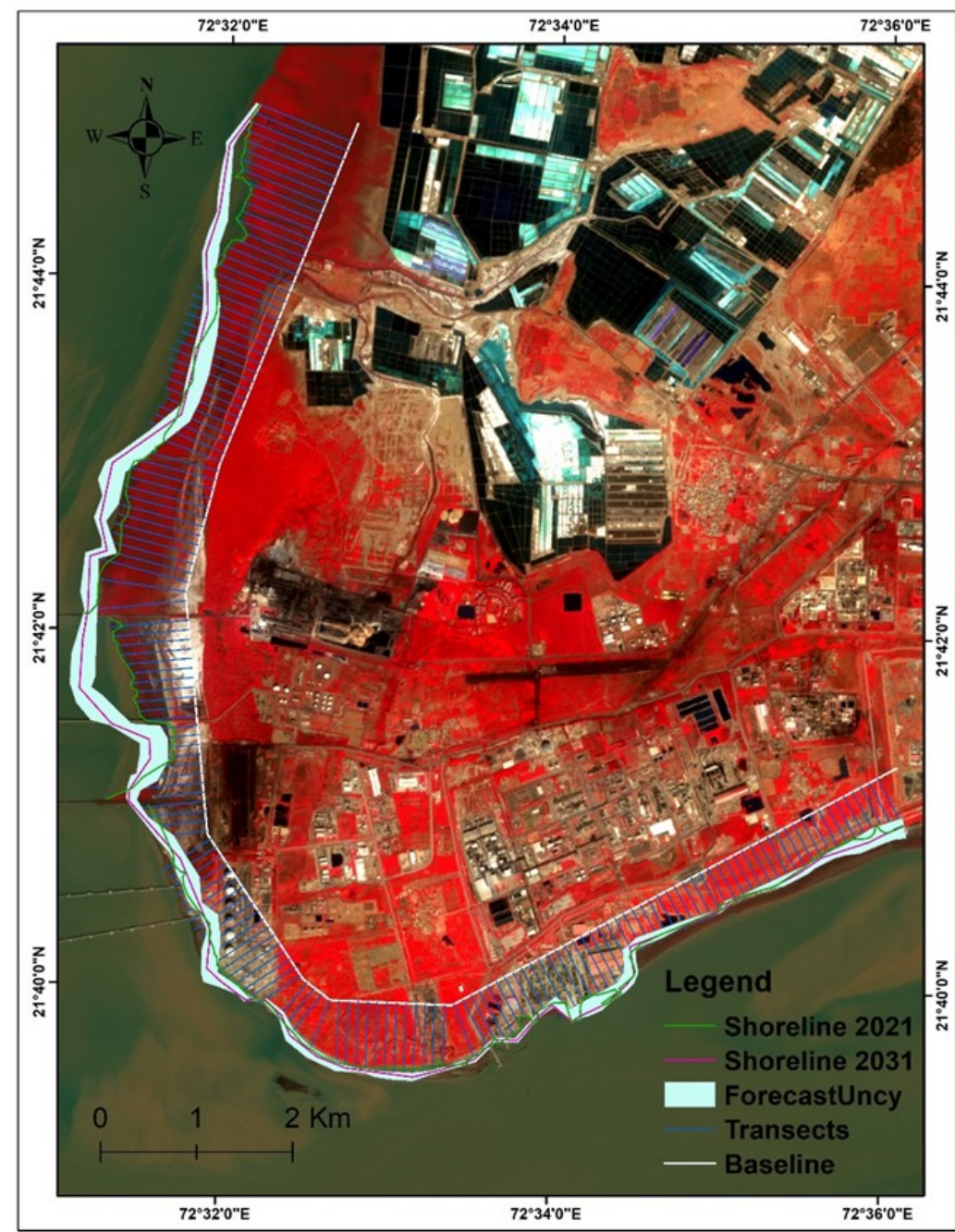

Figure 14. Map shows the shoreline position for the 2031

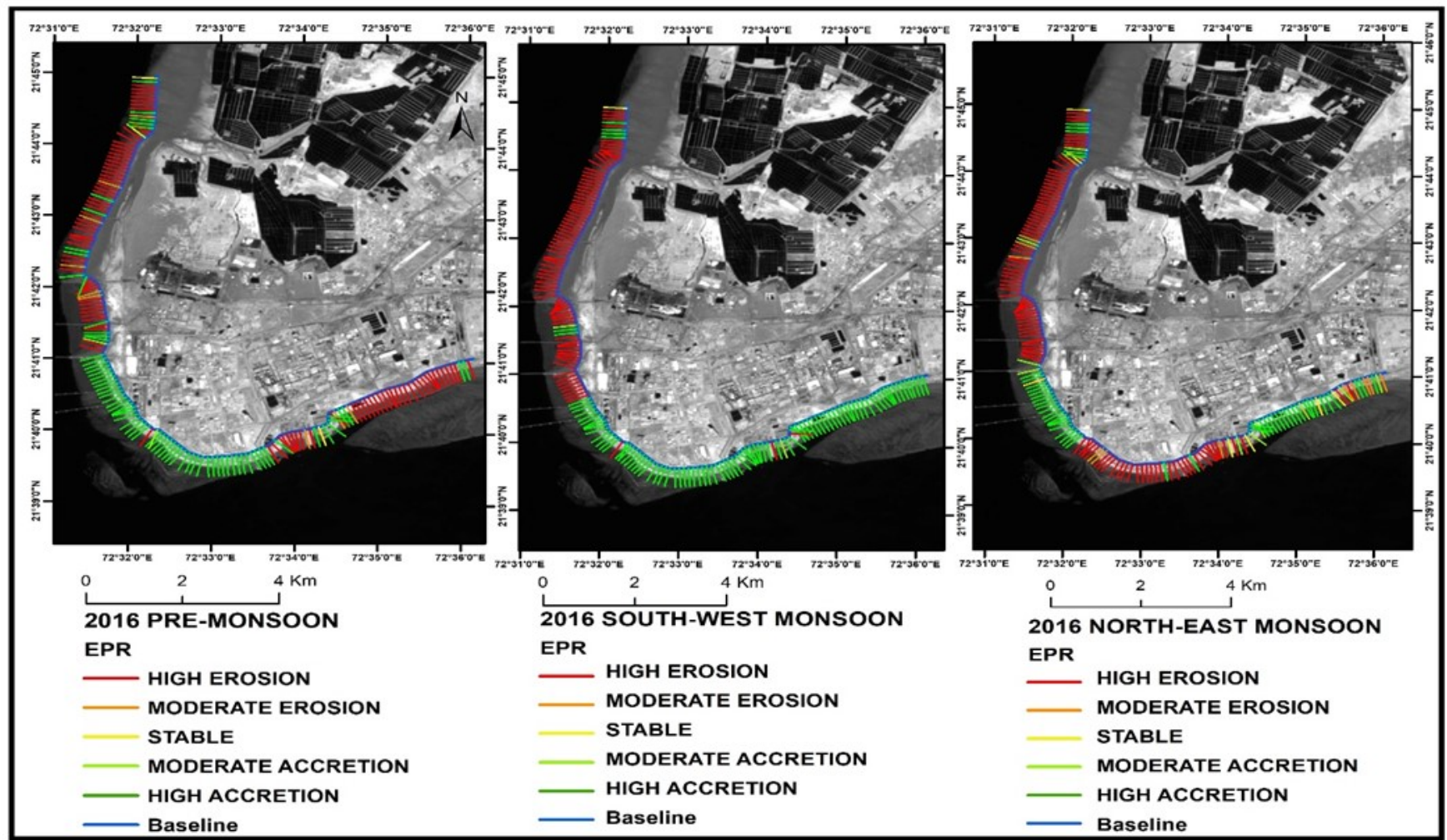

Figure 15.Seasonal change of shoreline 2016. 

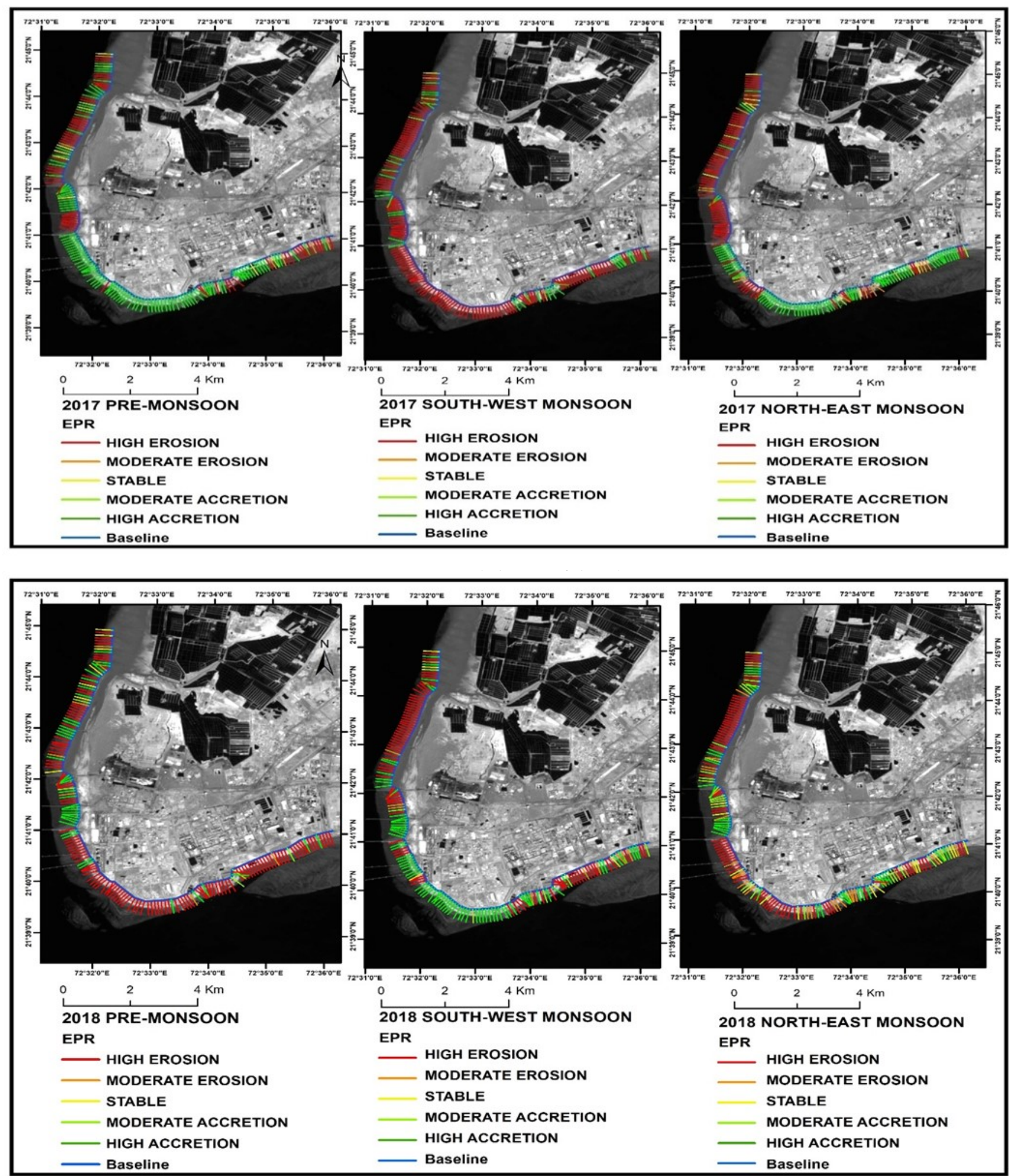

Figure 17. Seasonal change of shoreline 2018

uncertainty of forecast shows in polygon features around the line features. Figure 14. Shows the future shoreline position in Dahej coast. This measurement is fully model based therefore, we cannot say the result is accurate but, in this study, we can get an idea for the future. As we know the position of shoreline is highly dynamic in nature. Accretion of shoreline has a positive impact for the coastal area and erosion of shoreline has a negative impact. Therefore, prediction model can help for better planning and management of coastal land.
Seasonal change Rate of Shoreline

Rainfall is one of another climatic parameter which can effect on shoreline change but not for all areas. According to receiving of rainfall in a year, season divided into three types - Pre Monsoon, South-West Monsoon and North-East Monsoon. Pre-Monsoon season mainly found in the month of the year February to May. South-West Monsoon predominant in the month of the year June to September and North-East Monsoon is found from October to January. This region receives little rainfall throughout the year. The study of seasonal change of shoreline was done due to 
understanding is there any effect of seasonal rainfall to change the shoreline of that particular area. Seasonal change of the rate of shoreline has been carried out in the years 2016, 2017 and 2018. Three years a seasonal change has been carried out based on the availability of multi-dated satellite imageries. Map of seasonal change of shoreline change shows that the area is not that much effect by the rainfall. It has been found that, there is no seasonal similarity of change of rate during these 3 years. Only the year 2017, more erosion happened during the SW Monsoon period.

The present study attempt to detect the rate of change with very recent time period (2012-2021) which is very essential to continue monitoring the changes for coastal planning and management in this study area. It considers a transect-based study, in which certain crucial coastline characteristics may be lost in areas where no transects are available. This method is vital for environmental monitoring, it can be used extensively for basic research and comprehension. Beside, the estimation of shoreline position after 10 years will give a blueprint to the planners to understand the effect of shoreline changes and where the more erosion can take palce and where the accretion can take place. Those area with accretion will a good sign for the coastal environment but the erosional place need to take action by the planners from the effective damages. This study will be helpful for the government bodies, Gujrat maritime board, port authorities etc. as this regions are found most vulnerable to changes.

\section{Conclusion}

The actual purpose of this study was the application of Geospatial technology to better understand the shoreline change rate and forecasting of shoreline position. Erosion and accretion are highly fluctuating in nature due to semi-diurnal and mixed tide with high tidal range. Massive erosion also changes the coastal geomorphology of the study region. Extensive mudflats region facing more erosion due to its soft bottom sediments. Another outcome of erosion is the change of regional hydrodynamics. As the study area is having anthropogenic pressure and it is a hotspot of major anthropogenic activities, a proper study of the stability of mudflats and rate of sediment transportation and future prediction of the shoreline of the study region are essential for sustainable development. The three methods of rate calculation EPR, LRR, WLR are important but EPR can consider a quick measurement and easy to calculation on the other hand LRR and WLR is more reliable which is fully based on accepted statistical concept so it's purely computational. A clear seasonal pattern was not observed. The maximum and moderate erosion rates were more during the winter and pre-monsoon seasons compared to summer monsoon season in case of the year 2016 and 2018.

\section{References}

Appeaning Addo, K. (2015). Assessment of the Volta Delta Shoreline Change Coastal Zone Management Assessment of the Volta Delta Shoreline Change. J Coast Zone Manag, 18, 3. https://doi.org/10.4172/jczm.1000408

Bansal, P. (2020). International Conference on Innovative Advancement in Engineering and Technology (IAET-2020). 6.

Bhatti, H., Ramakrishnan, R., Sharma, A. K., \& Rajawat, A. S. (2018). Incessant Erosion of High Tidal Mudflats in the Northern Gulf of Khambhat. Current Science, 114(12), 2554. https://doi.org/10.18520/cs/v114/i12/2554-2558
Burningham, H., \& Fernandez-Nunez, M. (2020). Shoreline change analysis. In Sandy Beach Morphodynamics (pp. 439-460). Elsevier. https://doi.org/10.1016/B978-0-08-102927-5.00019-9

Himmelstoss, E. A., Henderson, R. E., Kratzmann, M. G., and Farris, A. S. (2018). Digital Shoreline Analysis System (DSAS) Version 5.0 User Guide. Downloded from https:// pubs.usgs.gov/of/2018/1179/ofr20181179.pdf

Gupta, M. (2014). Monitoring shoreline changes in the Gulf of Khambhat, India during 1966-2004 using RESOURCESAT-1 LISS-III. Open Journal of Remote Sensing and Positioning, 1 (1),27-37.

Jonah, F. E., Boateng, I., Osman, A., Shimba, M. J., Mensah, E. A., Adu-Boahen, K., ... Effah, E. (2016). Shoreline change analysis using end point rate and net shoreline movement statistics: An application to Elmina, Cape Coast and Moree section of Ghana's coast. Regional Studies in Marine Science, 7, 19-31. https://doi.org/10.1016/j.rsma.2016.05.003

Kankara, R. S., Selvan, S. C., Markose, V. J., Rajan, B., \& Arockiaraj, S. (2015). Estimation of long and short term shoreline changes along Andhra Pradesh coast using remote sensing and GIS techniques. Procedia Engineering, 116(1), 855-862. https:// doi.org/10.1016/j.proeng.2015.08.374

Kermani, S., Boutiba, M., Guendouz, M., Guettouche, M. S., \& Khelfani, D. (2016). Detection and analysis of shoreline changes using geospatial tools and automatic computation: Case of jijelian sandy coast (East Algeria). Ocean and Coastal Management, 132, 46-58. https://doi.org/10.1016/ j.ocecoaman.2016.08.010

Kuleli, T., Guneroglu, A., Karsli, F., \& Dihkan, M. (2011). Automatic detection of shoreline change on coastal Ramsar wetlands of Turkey. Ocean Engineering, 38(10), 1141-1149. https://doi.org/10.1016/j.oceaneng.2011.05.006

Long, J. W., \& Plant, N. G. (2012). Extended Kalman Filter framework for forecasting shoreline evolution: FORECASTING SHORELINE EVOLUTION. Geophysical Research Letters, 39 (13), n/a-n/a. https://doi.org/10.1029/2012GL052180

Mahapatra, M., Ratheesh, R., \& Rajawat, A.S. (2014). Shoreline change monitoring along the coast of south Gujrat, India using Digital Shoreline Analysis System. Journal of Indian Society and Remote Sensing, 42(4), 869-876.

Misra, A., \& Balaji, R. (2015). A study on the shoreline changes and Land-use/land-cover along the south Gujarat coastline. Procedia Engineering, 116(1), 381-389. https://doi.org/10.1016/ j.proeng.2015.08.311

Mohan, R. K., Short, A.D., Cambers, G., MacLeod, M., Cooper, J.A.G., Hopley, D., Scott, David, B., Craig-Smith, S. J. (2005) Coastal Changes, Rapid. Encyclopedia of Coastal Science, 253255. doi: 10.1007/1-4020-3880-1_76

Moussaid, J., Fora, A. A., Zourarah, B., Maanan, M., \& Maanan, M. (2015). Using automatic computation to analyze the rate of shoreline change on the Kenitra coast, Morocco. Ocean Engineering, 102, 71-77. https://doi.org/10.1016/ j.oceaneng.2015.04.044

Muskananfola, M. R., Supriharyono, \& Febrianto, S. (2020). Spatiotemporal analysis of shoreline change along the coast of Sayung Demak, Indonesia using Digital Shoreline Analysis System. Regional Studies in Marine Science, 34, 101060. https:// doi.org/10.1016/j.rsma.2020.101060

Mutaqin, B. W. (2017). Shoreline changes analysis in Kuwaru coastal area, Yogyakarta, Indonesia: An application of the Digital Shoreline Analysis System (DSAS). International Journal of Sustainable Development and Planning, 12(07), 1203 -1214. https://doi.org/10.2495/SDP-V12-N7-1203-1214

Nayak, R. K., \& Shetye, S. R. (2003). Tides in the Gulf of Khambhat, west coast of India. Estuarine, Coastal and Shelf Science, 57(12), 249-254. https://doi.org/10.1016/S0272-7714(02)00349-9

Nair, L., Sheela, Prasad, R., Rafeeque, M. K., and Prakash T.N., (2018). Coastal morphology and long-term shoreline changes along the southwest coast of India. Journal of Geological Society of India, 92, 588-595. DOI: 10.1007/s12594-018-1072-x 
Nayak, S. R., \& Sahai, B. (1985). Coastal morphology: A case study of the gulf of Khambhat (Cambay). International Journal of Remote Sensing, 6(3-4), 559-567. https:// doi.org/10.1080/01431168508948478

Nithu, R., Gurugnanam, B., Sudhakar, V., \& Glitson Francis, P. (2019). Estuarine shoreline change analysis along The Ennore river mouth, south east coast of India, using digital shoreline analysis system. Geodesy and Geodynamics, 10(3), 205-212. https://doi.org/10.1016/j.geog.2019.04.002

Shaikh, M. G., Nayak, S., Shah, P. N., \& Jambusaria, B. B. (1989). Coastal landform mapping around the Gulf of Khambhat using Landsat TM data. Journal of the Indian Society of Remote Sensing, 17(1), 41-48. https://doi.org/10.1007/BF02995964

Sheik, M., \& Chandrasekar. (2011). A shoreline change analysis along the coast between Kanyakumari and Tuticorin, India, using digital shoreline analysis system. Geo-Spatial Information Science, 14(4), 282-293. https://doi.org/10.1007/s11806-0110551-

Shin, B., \& Kim, K. (2015). Estimation of shoreline change using high resolution images. In Procedia Engineering (Vol. 116, pp. 994-1001). Elsevier Ltd. https://doi.org/10.1016/ j.proeng.2015.08.391

Thangaraj, K. (2019). Mapping of shoreline changes in between Devipattinam and Micro Level Mapping of Morphological Changes in the Beaches Caused by Tsunami in between Cuddalore and Nagapattinam, Tamilnadu, East Coast of India View project GEOMATICS IN FLOOD WATER HARVESTING AND MANAGEMENT PARTS OF TIRUCHIRAPPALLI DISTRICT TAMIL NADU View project. Retrieved from https://www.researchgate.net/ publication/330712090

Vivek, G., Goswami, S., Samal, R. N., \& Choudhury, S. B. (2019). Monitoring of Chilika Lake mouth dynamics and quantifying rate of shoreline change using 30冈m multi-temporal Landsat data. Data in Brief, 22, 595-600. https://doi.org/10.1016/ j.dib.2018.12.082

Yadav, A., Dodamani, B. . M., \& Dwarakish, G. S. (2018). SHORELINE CHANGE THREAT TO COASTAL ZONE: A CASE STUDY OF KARWAR COAST (pp. 18-30). https:// doi.org/10.17501/2513258X.2018.2202 